\title{
Otoferlin Is Critical for a Highly Sensitive and Linear Calcium-Dependent Exocytosis at Vestibular Hair Cell Ribbon Synapses
}

\author{
Didier Dulon, ${ }^{1 \star}$ Saaid Safieddine, ${ }^{2 \star}$ Sherri M. Jones, ${ }^{3}$ and Christine Petit ${ }^{2,4}$ \\ ${ }^{1}$ Université Victor Segalen Bordeaux 2, Institut des Neurosciences de Bordeaux, Equipe Neurophysiologie de la Synapse Auditive, Inserm, Unité Mixte de \\ Recherche en Santé 587, Centre Hospitalier Universitaire Hôpital Pellegrin, 33076 Bordeaux, France, ${ }^{2}$ Institut Pasteur et Université Pierre et Marie Curie, \\ Unité de Génétique et Physiologie de l'Audition, Inserm Unité Mixte de Recherche en Santé 587, 75015 Paris, France, ${ }^{3}$ Department of Communication \\ Sciences and Disorders, East Carolina University, Greenville, North Carolina 27858, and ${ }^{4}$ Collège de France, 75005 Paris, France
}

Otoferlin, a C2-domain-containing $\mathrm{Ca}^{2+}$ binding protein, is required for synaptic exocytosis in auditory hair cells. However, its exact role remains essentially unknown. Intriguingly enough, no balance defect has been observed in otoferlin-deficient $\left(\right.$ Otof $\left.{ }^{-1-}\right)$ mice. Here, we show that the vestibular nerve compound action potentials evoked during transient linear acceleration ramps in Otof $^{-1-}$ mice display higher threshold, lower amplitude, and increased latency compared with wild-type mice. Using patch-clamp capacitance measurement in intact utricles, we show that type I and type II hair cells display a remarkable linear transfer function between $\mathrm{Ca}^{2+}$ entry, flowing through voltage-activated $\mathrm{Ca}^{2+}$ channels, and exocytosis. This linear $\mathrm{Ca}^{2+}$ dependence was observed when changing the $\mathrm{Ca}^{2+}$ channel open probability or the $\mathrm{Ca}^{2+}$ flux per channel during various test potentials. In $\mathrm{Otof}^{-1-}$ hair cells, exocytosis displays slower kinetics, reduced Ca ${ }^{2+}$ sensitivity, and nonlinear $\mathrm{Ca}^{2+}$ dependence, despite morphologically normal synapses and normal $\mathrm{Ca}^{2+}$ currents. We conclude that otoferlin is essential for a high-affinity $\mathrm{Ca}^{2+}$ sensor function that allows efficient and linear encoding of low-intensity stimuli at the vestibular hair cell synapse.

\section{Introduction}

In cochlear hair cells, synaptic transmission involves a highly coordinated process of multivesicular release that is triggered by $\mathrm{Ca}^{2+}$ ions flowing through nearby clustered L-type $\mathrm{Ca}^{2+}$ channels containing the $\mathrm{Ca}_{\mathrm{v}} 1.3\left(\alpha_{1 \mathrm{D}}\right)$ subunit (Glowatzki and Fuchs, 2002; Brandt et al., 2005). Remarkably, a linear relationship is found between the hair cell $\mathrm{Ca}^{2+}$ current and synaptic vesicle exocytosis (Johnson et al., 2005; Schnee et al., 2005; Beurg et al., 2008). Also, the synaptic transfer function relating presynaptic $\mathrm{Ca}^{2+}$ current and postsynaptic afferent activity operates in a very efficient linear regimen (Keen and Hudspeth, 2006; Goutman and Glowatzki, 2007). This linear synaptic transfer function enables sensory information from small graded receptors potentials to be transferred with minimal distortion across the synapse, as in photoreceptors (Thoreson, 2007).

It has been suggested that otoferlin, a large transmembrane vesicular $\mathrm{Ca}^{2+}$ binding protein with six $\mathrm{C} 2$ domains operates as

Received March 1, 2009; revised July 7, 2009; accepted July 8, 2009.

This work was supported by National Institutes of Health Grant ROI DCOD6443 (S.M.J.), European Commission FP6 Integrated Project EuroHear Grant LSHG-CT-2004-512063 (C.P.), Agence Nationale de la Recherche Grant ANR07-Neuro-036-01 (S.S.), and the Fondation Voir et Entendre (D.D.). We thank Emilie Hoang Dinh, Yohan Bouleau, Bruce Mock, and Isabelle Roux for their assistance in some of the experiments, Tim Jones and Maryline Beurg for helpful discussion, and Jean-Pierre Hardelin for critical reading of this manuscript. We thank Pierre Costet for raising the mouse colony at Bordeaux 2 university.

${ }^{*}$ D.D. and S.S. contributed equally to this work.

Correspondence should be addressed to Didier Dulon, Université Victor Segalen Bordeaux 2, Institut des Neurosciences de Bordeaux, Equipe Neurophysiologie de la Synapse Auditive, Inserm, Unité Mixte de Recherche en Santé 587, Centre Hospitalier Universitaire Hôpital Pellegrin, 33076 Bordeaux, France. E-mail: didier.dulon@inserm.fr.

DOI:10.1523/JNEUROSCI.1009-09.2009

Copyright $\odot 2009$ Society for Neuroscience ～0270-6474/09/2910474-14\$15.00/0 the main $\mathrm{Ca}^{2+}$ sensor for neurotransmitter release at auditory hair cell ribbon synapses (Yasunaga et al., 1999; Roux et al., 2006). Otoferlin-null (Otof ${ }^{-1}$ ) mice have a very severe hearing impairment as a result of the failure of $\mathrm{Ca}^{2+}$-evoked exocytosis in cochlear hair cells (Roux et al., 2006; Beurg et al., 2008). Otoferlin localizes to ribbon-associated vesicles and interacts, in a $\mathrm{Ca}^{2+}$. dependent manner, with the SNARE (SNAP receptor) complex proteins syntaxin-1 and SNAP25 (synaptosome-associated protein of $25 \mathrm{kDa}$ ) in vitro. Moreover, the $\mathrm{C} 2 \mathrm{D}$ domain of otoferlin can bind to the $\mathrm{Ca}_{\mathrm{v}} 1.3$ subunit of the calcium channel in vitro (Ramakrishnan et al., 2009).

Synaptic vesicle exocytosis in mammalian vestibular hair cells has, however, not been explored. Like cochlear hair cells, vestibular hair cells express L-type $\mathrm{Ca}^{2+}$ channels containing the $\mathrm{Ca}_{\mathrm{v}} 1.3$ subunit (Bao et al., 2003; Dou et al., 2004) and otoferlin (Yasunaga et al., 1999; Roux et al., 2006; Schug et al., 2006). This protein could thus operate as a $\mathrm{Ca}^{2+}$ sensor for neurotransmitter release in vestibular hair cells too. Despite the fact that Otof ${ }^{-1-}$ mice have no apparent vestibular dysfunction in gross behavior tests (Roux et al., 2006; Schwander et al., 2007), a subtle defect at vestibular hair cell synapses may have been overlooked.

The mammalian vestibular sensory organs are generally described as low-frequency analyzers of head motion from a few hertz down to stationary position (head tilt), yet the vestibular hair cell synapses work with a temporal precision in the millisecond range. Notably, the latency of onset of head motion to onset of eye movement in the vestibular ocular reflex is below $10 \mathrm{~ms}$ (Huterer and Cullen, 2002). Vestibular nerve fibers show a remarkable linear relationship between the action potential dis- 
charge rate and the velocity of head rotation (Goldberg and Fernandez, 1971; Hullar and Minor, 1999). These characteristics of linearity and temporal precision, which are similar to those found in auditory hair cells, prompted us to characterize the $\mathrm{Ca}^{2+}$ dependence and kinetics of synaptic exocytosis in mouse vestibular hair cells and study the possible role of otoferlin in these properties.

\section{Materials and Methods}

\section{Gravity receptor function: vestibular-evoked potentials}

The use of mice herein was approved by the Institutional Animal Care and Use Committee at East Carolina University. Mice were anesthetized by intraperitoneal injections of a ketamine $(75 \mathrm{mg} / \mathrm{kg})$ and xylazine $(8$ $\mathrm{mg} / \mathrm{kg}$ ) mixture. Core body temperature was maintained at $37.0 \pm 0.2^{\circ} \mathrm{C}$ using a homeothermic heating blanket system (FHC Inc.).

Vestibular-evoked potential (VsEP) recordings were based on methods published by Jones et al. (1999, 2006). These methods were modified for the present study to use a noninvasive coupling system for securing the head to the mechanical shaker. Stimuli were delivered to the head using a voltage-controlled mechanical shaker. The head was coupled to a custom platform with a custom head clip. The head clip was a lightweight plastic spring hair clip with tines modified to encircle the head anterior to the pinnae. The spring clip was screwed to the custom platform mounted to the mechanical shaker. Stainless steel wire was placed subcutaneously at the nuchal crest to serve as the non-inverting electrode. Needle electrodes were placed posterior to the right pinna and at the ventral neck for inverting and ground electrodes, respectively. Traditional signal averaging was used to resolve responses in electrophysiological recordings. Ongoing electroencephalographic activity was amplified $(200,000 \times)$, filtered $(300-3000 \mathrm{~Hz},-6 \mathrm{~dB}$ amplitude points), and digitized (1024 points, $10 \mu \mathrm{s}$ /point). A total of 256 primary responses were averaged for each VsEP response waveform. All responses were replicated.

Linear acceleration pulses, 2 ms duration, were presented to the cranium in the naso-occipital axis using two stimulus polarities, normal and inverted. Stimuli were presented at a rate of 17 pulses/s. Stimulus amplitude ranged from +6 to $-18 \mathrm{~dB}$, re: $1.0 \mathrm{~g} / \mathrm{ms}$ (where $1 \mathrm{~g}=9.8 \mathrm{~m} / \mathrm{s}^{2}$ ) adjusted in $3 \mathrm{~dB}$ steps. A broadband forward masker $(50-50,000 \mathrm{~Hz}, 97$ $\mathrm{dB}$ sound pressure level) was presented during VsEP measurements to verify the absence of cochlear responses. Recordings began at the maximum stimulus intensity (i.e., $+6 \mathrm{~dB}$, re: $1.0 \mathrm{~g} / \mathrm{ms}$ ) with and without acoustic masking, and then intensity was dropped to $-18 \mathrm{~dB}$ and raised in $3 \mathrm{~dB}$ steps to complete an intensity profile. The first three positive and negative response peaks were scored. The first response peak (i.e., $\mathrm{P} 1$ and N1) was used for analyses because this peak represents compound neural activity from the peripheral vestibular nerve (Nazareth and Jones, 1998). Response peak latency for P1 (measured in milliseconds), peak-to-peak amplitude for P1-N1 (measured in microvolts), and thresholds (measured in decibels, re: $1.0 \mathrm{~g} / \mathrm{ms}$ ) were quantified. Linear regression was used to obtain the latency-intensity and amplitude-intensity slopes for each animal on the unweighted raw data. Descriptive statistics were generated for each genotype. Variability is reported as $\mathrm{SD}$, unless otherwise stated. Independent samples $t$ test was used to compare P1 latency, P1-N1 amplitude, VsEP thresholds, and slopes between genotypes.

Mice were obtained by interbreeding of $\mathrm{Otof}^{+/-}$heterozygote mice. Tail DNA genotyping was done by PCR (REDExtract-N-Amp tissue PCR kit; Sigma) using primers 5'-CACTTGCTTTGTCTCATCTCC-3' and $5^{\prime}$-GTCACTTCTTCTGGGTATTTC- $3^{\prime}$. The following PCR products were generated: a single $1.23 \mathrm{kbp}$ product for wild-type $\left(\mathrm{Otof}^{+/+}\right)$mice, a single 507 bp product for knock-out homozygote (Otof ${ }^{-1}$ ) mice, and both PCR products for $\mathrm{Otof}^{+/-}$mice (Roux et al., 2006). VsEPs were studied in 2-month-old Otof ${ }^{+/+}$, Otof $^{+/-}$, and Otof ${ }^{-1-}$ mice $(n=5, n=$ 11 , and $n=9$, respectively). No significant differences (latency - threshold) were found between $\mathrm{Otof}^{+/+}$and $\mathrm{Otof}^{+/-}$mice (data not shown).

Recordings from the mouse vestibular utricle

Organ preparation. The study on exocytosis was performed on 36 mice $\left(12 \mathrm{Otof}^{+/+}, 8 \mathrm{Otof}^{+/-}\right.$, and $\left.16 \mathrm{Otof}^{-/-}\right)$, ages postnatal day 4 (P4) to P9 issued from 12 different litters. Recordings of firing activity on type I calyx endings were performed on a total of 14 P17-P30 mice issued from four different litters (nine Otof ${ }^{+/+}$and five $\mathrm{Otof}^{-1-}$ ). Neonatal mice were obtained by interbreeding of heterozygotes mice Otof ${ }^{+/-}$. Recordings and analysis were performed before knowing the mice genotype. All experiments were performed in accordance with Inserm and Pasteur Institute welfare guidelines. Care was taken to minimize animal pain. Mice were deeply anesthetized when necessary, with a rodent mixture [ketamine at $50 \mathrm{mg} / \mathrm{kg}$ (PanPharma) and Rompun at $5 \mathrm{mg} / \mathrm{kg}$ (Bayer Pharma)].

Experiments were performed on freshly dissected utricular organs from which otoconia were carefully removed from the upper surface of the sensory epithelium after a light enzymatic digestion with proteinase XXIV ( $50 \mu \mathrm{g} / \mathrm{ml}$ for $5 \mathrm{~min}$; Sigma). The extraction from the temporal bone and the dissecting step of the utricle were performed in a cold $\left(5-10^{\circ} \mathrm{C}\right)$ perilymph-like solution [in mM: $135 \mathrm{NaCl}, 5.8 \mathrm{KCl}, 1.3 \mathrm{CaCl}_{2}$, $0.9 \mathrm{MgCl}_{2}, 0.7 \mathrm{NaH}_{2} \mathrm{PO}_{4}, 5.6 \mathrm{D}$-glucose, $2 \mathrm{Na}$-pyruvate, and $10 \mathrm{Na}$ HEPES, pH 7.4 (osmolality near $300 \mathrm{mmol} / \mathrm{kg}$ )]. The dissected sensory organ was then fixed flat, with sterocilia bundles facing up, under a network of dental floss strands anchored at the bottom of the experimental perfusion chamber ( $\mathrm{PC}-\mathrm{H}$ chamber from Siskiyou). The recording chamber was filled with $2 \mathrm{ml}$ of perilymph [supplemented with $1 \mu \mathrm{M}$ TTX (Sigma), $10 \mathrm{~mm}$ tetraethylammonium (TEA)-Cl, and $100 \mathrm{~nm}$ apamin (Latoxan); during $I_{\mathrm{Ca}}$ and $\Delta C_{\mathrm{m}}$ recordings], and the organ was continuously perfused at room temperature $\left(22-24^{\circ} \mathrm{C}\right)$ at a rate of $100 \mu \mathrm{l} / \mathrm{min}$ using a Masterflex LS pump (Cole Parmer Instrument Company). The sensory hair cells were viewed through a $40 \times$ LWD water-immersion objective (numerical aperture 0.8 ) on an Olympus BX51WI microscope.

Electrophysiology. Ruptured-patch whole-cell recordings were obtained using 3-4 M $\Omega$ electrodes pulled from borosilicate glass capillaries (1B150F-4; WPI) on a Sachs-Flaming Microelectropuller (model PC-84; Sutter Instruments). The tip of the recording patch pipettes were carefully fire polished with a microforge (MF-830; Narishige) to improve seal resistance stability and coated with ski wax (SWIX) to minimize pipette capacitance. The internal pipette solution contained the following (in mM): $150 \mathrm{CsCl}, 1 \mathrm{MgCl}_{2}$, 5 TEA-Cl, 1 EGTA, $5 \mathrm{Na}_{2} \mathrm{ATP}, 0.5 \mathrm{Na}_{2} \mathrm{GTP}$, and 5 Cs-HEPES, pH 7.4 (osmolality near $300 \mathrm{mmol} / \mathrm{kg}$ ). A liquid junction potential of $\sim 2 \mathrm{mV}$ (not corrected in our recordings) was measured between the internal pipette solution and the external solution.

Real-time changes in membrane capacitance $\left(\Delta C_{\mathrm{m}}\right)$ were made using the "track-in" circuitry of the Optopatch amplifier (Cairn Research) as described previously by Johnson et al. (2002). A $2.5 \mathrm{kHz}$ sine wave of $18-20 \mathrm{mV}$ was applied to the cells from a holding potential of $-80 \mathrm{mV}$. The amplifier output of membrane current, membrane capacitance, and series resistance were acquired and analyzed with a Digidata 1320A interface and pClamp 10 software (Molecular Devices). $C_{\mathrm{m}}$ signals were low-pass filtered at $80 \mathrm{~Hz} . \Delta C_{\mathrm{m}}$ responses were measured $50 \mathrm{~ms}$ after the end of the depolarizing pulse and averaged over a period of 100-300 ms.

Type I and type II hair cells were essentially recorded from the central part of the utricle near the striola zone. Passive membrane properties and access resistance of hair cells were assessed using the membrane test function in Clampex (pClamp 10). No significant differences in $C_{\mathrm{m}}$ and series resistance $\left(R_{\mathrm{s}}\right)$ were observed between wild-type [type I: $R_{\mathrm{s}}=$ $11.46 \pm 1.25 \mathrm{M} \Omega$ with $C_{\mathrm{m}}=4.11 \pm 0.13 \mathrm{pF}(n=45)$; type II: $R_{\mathrm{S}}=11.22$ $\mathrm{M} \Omega \pm 1.27$ with $C_{\mathrm{m}}=3.91 \pm 0.14 \mathrm{pF}(n=16)$ ] and Otof $^{-1-}$ [type I: $R_{\mathrm{s}}=11.07 \pm 0.60 \mathrm{M} \Omega$ with $C_{\mathrm{m}}=4.24 \pm 0.24 \mathrm{pF}(n=23)$; type II: $R_{\mathrm{S}}=$ $11.23 \pm 0.81 \mathrm{M} \Omega$ with $\left.C_{\mathrm{m}}=4.29 \pm 0.16 \mathrm{pF}(n=19)\right]$ hair cells. Hair cells that did not present stable $R_{\mathrm{s}}$ during experimental recordings were discarded.

For the recordings of spontaneous postsynaptic firing activity (action potentials), cell-attached loose patch recordings $\left(R_{\text {seal }}=15-100 \mathrm{M} \Omega\right)$ from type I hair cell calyces were done in normal $1.3 \mathrm{mM} \mathrm{Ca}^{2+}$ perilymph by using 5-6 $\mathrm{M} \Omega$ electrodes pulled from similar glass capillaries. The amplifier was set in either the current- or voltage-clamp mode and held at the zero current potential, with no current injection, with low pass-filter set at $10 \mathrm{kHz}$. For spontaneous EPSCs recordings, cell-attached tight seals $\left(R_{\text {seal }}=4.4 \pm 0.6 \mathrm{G} \Omega\right)$ were performed on type I hair cell calyces under voltage clamp at $-80 \mathrm{mV}$ in the presence of $1 \mu \mathrm{M}$ TTX. We used Mini Analysis Program 6.03 (Synaptosoft) to detect and analyze the peaks of 
spontaneous miniature synaptic currents. Peak events were detected automatically using an amplitude threshold, two times the average root mean square noise $(\sim 5 \mathrm{pA})$. It is to be noted that our settings of the program analysis, i.e., threshold and period to search $(5 \mathrm{~ms})$, resulted in the treatment of most multiphasic events as single peaks. To block spontaneous activity, the preparation was perfused with $50 \mu \mathrm{M}$ NBQX for at least $10-15$ min (Tocris Bioscience).

Identification of type I and type II hair cells. Under differential contrast microscopy, by focusing up and down into the preparation, type I hair cells were recognized with surrounding single or multiple calyces. Furthermore, type I hair cells could also be identified from type II hair cells in our electrophysiological recordings by the expression of $g_{\mathrm{KL}}$, a specific conductance partially permeable to $\mathrm{Cs}^{+}$ions and activated near resting potentials (Rüsch et al., 1998; Bao et al., 2003). Hair cells presenting a slowly activating outward $\mathrm{Cs}^{+}$conductance at positive potentials were considered to be of type I, whereas other cells were considered of type II. Although our recordings were essentially made in the striola area of the utricle in which faster maturation occurs, it is still possible that some of the hair cells termed type II may correspond to undifferentiated type I hair cells that are not yet expressing $g_{\mathrm{KL}}$ and have incomplete calyces at P4-P9 (Rüsch et al., 1998). In our experimental conditions, using an intracellular recording solution containing $150 \mathrm{~mm} \mathrm{CsCl}$, the activation time and amplitude of $g_{\mathrm{KL}}$ was low enough to allow the recording of the voltage-activated $\mathrm{Ca}^{2+}$ currents $\left(I_{\mathrm{Ca}}\right)$ in type I hair cells.

Curve fitting and statistical analysis. Curve fitting and statistical analysis were done using Origin software (OriginLab) and GraphPad Software. The criterion for statistical significance was chosen to be $p<0.05$ and evaluated with $F$ tests and Student's $t$ test or two-way ANOVA. Variability is reported as \pm SEM, unless otherwise stated. Because recordings from $\mathrm{Otof}^{+/+}$and $\mathrm{Otof}^{+/-}$vestibular hair cells did not show significant difference in $I_{\mathrm{Ca}}$ and $\Delta C_{\mathrm{m}}$, these data were pooled in the same group, referred to as "wild-type."

\section{Immunohistofluorescence}

Inner ear tissue preparation and immunohistochemistry for the light microscope were performed as reported previously (Roux et al., 2006) on 7 - and 30-d-old mice. Inner ear sections $(10 \mu \mathrm{m})$ were washed three times in PBS, preincubated in PBS solution supplemented with $20 \%$ of normal goat serum for $1 \mathrm{~h}$, and incubated with a mixture of a polyclonal antibody directed against otoferlin (1:500) and a monoclonal anti- $\beta$ tubulin III antibody (1:200; Sigma) overnight at $4^{\circ} \mathrm{C}$. After three washes in PBS, sections were incubated for $1 \mathrm{~h}$ with $\mathrm{F}(\mathrm{ab})_{2}^{\prime}$ fragment of goat anti-rabbit IgG antibody conjugated with Alexa488 fluorescein (Interchim) or goat anti-mouse IgG antibody conjugated with cyanine $3 \mathrm{flu}-$ orophore (Jackson ImmunoResearch) diluted at 1:500 in PBS. Sections were then washed three times in PBS and finally covered by one drop of Fluorsave medium (Biochem Laboratories).

For ribbon quantification, utricular whole-mount preparations fixed with $4 \%$ paraformaldehyde (PFA) in PBS were permeabilized with $0.3 \%$ Triton X-100 in PBS containing 20\% normal goat serum for $1 \mathrm{~h}$ at room temperature. The primary antibodies against myosin VIIA, CtBP2, and GluR2-GluR3 were used at dilutions of 1:100, 1:500, and 1:200, respectively. Microphotographs were made using a confocal laser scanning microscope LSM510 Meta (Carl Zeiss, Pasteur Institute, Imageople).

\section{Electron microscopy}

Inner ears from 6-d-old mice were fixed as described previously (Roux et al., 2006). The vestibular end organs were microdissected out individually and were processed by the progressive temperaturelowering technique. Ultrathin sections $(70 \mathrm{~nm})$ were cut with a Leica Ultracut S microtome and transferred to Formvar-coated single-slot grids. Immunogold labeling was performed as described previously (Roux et al., 2006). The sections were incubated overnight with otoferlin or antibodies diluted to 1:200, washed, and then incubated for $2 \mathrm{~h}$ with 10 $\mathrm{nm}$ gold-conjugated goat anti-mouse or goat anti-rabbit antibodies (1: 50; Tebu). The sections were then stained with uranyl acetate and lead citrate and examined under a JEOL 1200EX electron microscope. For morphological analyses, inner ears were perfused with 4\% PFA and $2 \%$ glutaraldehyde in PBS, pH 7.4, and immersed in the fixative solution for
$2 \mathrm{~h}$. They were then postfixed by overnight incubation in $1 \%$ osmium tetraoxide at $4^{\circ} \mathrm{C}$, dehydrated in graded acetone concentrations, and embedded in Spurr's low-viscosity epoxy resin hardened at $70^{\circ} \mathrm{C}$. Ultrathin sections were transferred to Formvar-coated single-slot grids, stained with uranyl acetate and lead citrate, and examined under a JEOL 1200EX electron microscope) (Pasteur Institute, Imageopole).

\section{Results}

\section{Gravity receptor function is affected in otoferlin-deficient mice}

Gravity receptor function that arises from the otolithic vestibular organs, utricle and saccule, was analyzed in 2-month-old mutant mice lacking otoferlin (Otof $\left.{ }^{-/}\right)$, by recording compound action potentials of the vestibular nerve and central relays (VsEPs) during linear acceleration ramps (Jones et al., 1999; 2006). Typical VsEP waveforms recorded from $\mathrm{Otof}^{+/-}$and Otof ${ }^{-/-}$mice are shown in Figure $1 A$. Table 1 lists the means and SDs for thresholds latencies and amplitudes of the first two positive (P1, P2) and negative (N1, N2) peaks of VsEPs.

The first response peak P1 was used for statistical analyses, because it is produced by the peripheral portion of the vestibular nerve and would be affected by a hair cell synaptic defect. At the maximum stimulus intensity presented $(+6 \mathrm{~dB}$, re: $1.0 \mathrm{~g} / \mathrm{ms}), \mathrm{P} 1$ latency was significantly longer $(p<0.05)$ (Fig. $1 B)$, P1-N1 amplitude was significantly smaller $(p<0.05)$ (Fig. $1 C)$, and thresholds were significantly higher $(p<0.05)$ (Table 1$)$ for Otof $^{-/-}$mice than for Otof ${ }^{+/-}$mice.

Response peak latency for P1 decreased linearly with increasing stimulus intensity (Fig. $1 B$ ). Linear fit of the latency decrease from individual animals gave a similar slope between Otof ${ }^{-1-}$ and Otof $^{+/-}$mice $(21.08 \pm 3.85$ vs $21.47 \pm 4.70 \mu \mathrm{s} / \mathrm{dB}$, respectively). However, P1 latency was significantly prolonged for all stimuli tested in the Otof ${ }^{-1-}$ mice as shown in the averaged data (Fig. $1 B$ ). Prolonged latencies are consistent with a presynaptic defect producing delayed or reduced release of neurotransmitter from the hair cells. In heterozygote or wild-type mice, P1-N1 response amplitudes showed a near linear relationship with stimulus intensity. The amplitude-intensity slope $(0.05 \pm 0.02 \mu \mathrm{V} /$ $\mathrm{dB})$ is consistent with values reported previously in other rodents (Jones et al., 1999; 2006). In contrast, in Otof ${ }^{-1-}$ mice, the synaptic transfer function between $\mathrm{P} 1-\mathrm{N} 1$ response amplitudes and stimulus amplitude was significantly reduced $(0.03 \pm 0.02 \mu \mathrm{V} /$ $\mathrm{dB} ; p<0.05)$. Response amplitudes pooled across animals for each genotype could be fitted by a power function with $N=1.09$ and $N=4.11$ for $O t o f^{+/-}$and Otof ${ }^{-1-}$, respectively (Fig. 1C).

Overall, these results suggest that otoferlin knock-out mice have functional deficits of the peripheral gravity receptors. Notably, a previous study of deaf5/deaf5 mice carrying a missense mutation in Otof did not observe VsEP defects (Longo-Guess et al., 2007). However, response parameters (latency and amplitude) were not quantified. Moreover, a missense mutation that substitutes an isoleucine for an asparagine in the C2B domain of the protein may have a different phenotype from the Otof knockout mice examined herein.

\section{Spontaneous synaptic activity is not affected in utricular hair cells lacking otoferlin}

In the vestibular organs, two types of hair cells are described according to their synaptic terminal: type I and type II hair cells (for review, see Goldberg, 1991; Eatock et al., 2008). Type I hair cells are enveloped by a single calyx nerve ending, and type II hair cells receive several bouton endings (see Fig. 9). We took advantage of the large calyx endings surrounding type I hair cells to 

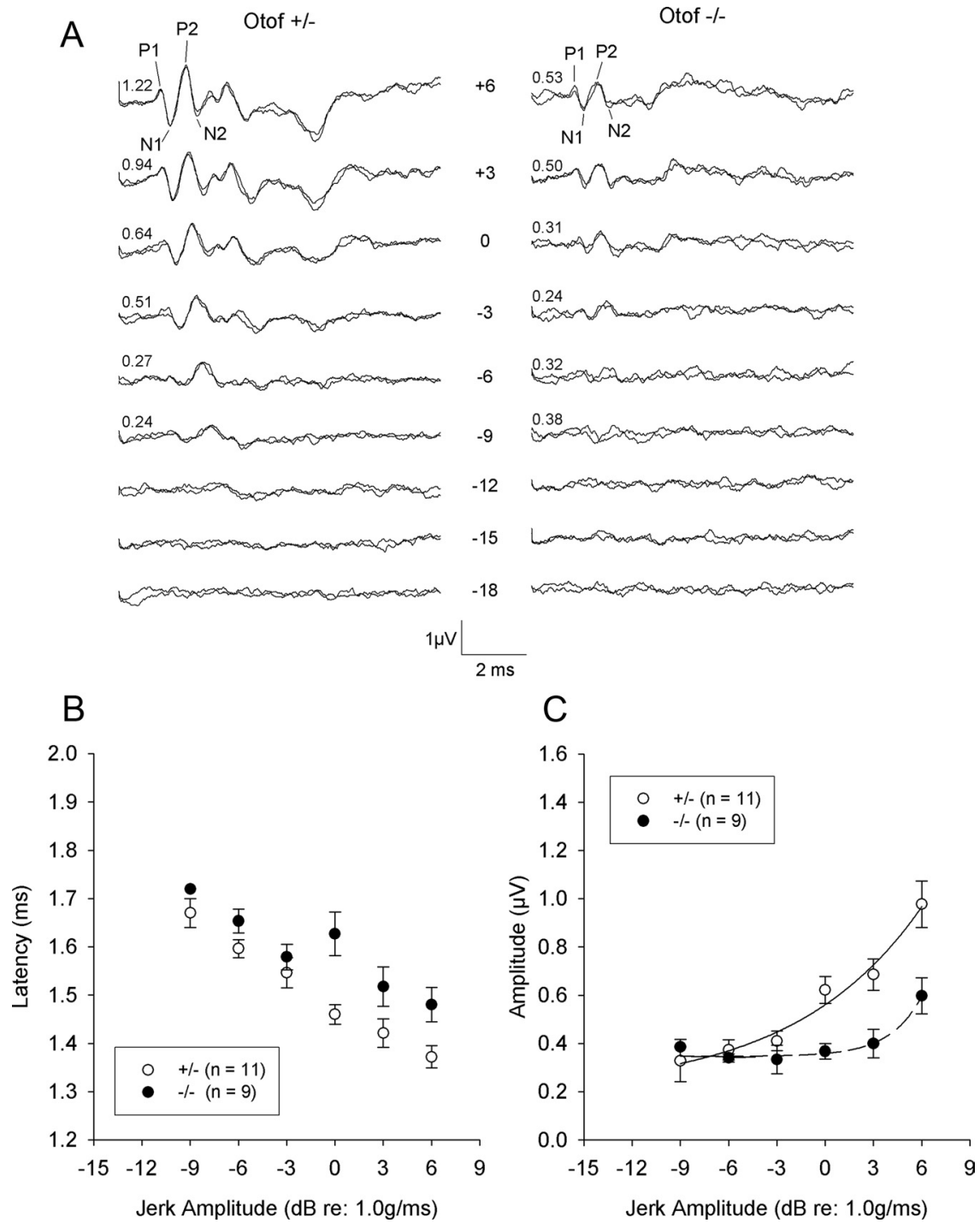

Figure 1. Gravity receptor potentials indicate a reduced firing synchrony of $\mathrm{Otof}^{-1-}$ vestibular neurons. Eighth nerve vestibular compound action potentials (VsEPs) were recorded from the surface of the mouse skull during transient linear acceleration ramps. $A$, Representative VsEP waveforms for one $\mathrm{Otof}^{+/-}$mouse (left) and one Otof ${ }^{-1-}$ mouse (right). Stimulus levels are in decibels (re: $1.0 \mathrm{~g} / \mathrm{ms}$ ) and show a decreasing intensity series from +6 to $-18 \mathrm{~dB}$. Two traces are shown for each stimulus level to demonstrate reproducibility. Values at the left end of each trace pair represent the P1-N1 amplitude measured for the pair. Conspicuous differences in response peak amplitudes can be seen between the two genotypes. $B, C$, Response peak latencies and amplitudes at various stimulus levels (means \pm SEM). Open symbols represent heterozygotes 0 tof $^{+/-}$, and filled symbols represent homozygote knock-out ( $\left(\mathrm{tof}^{-1-}\right)$ mice. In $\mathrm{C}$, the transfer functions of the vestibular nerve responses (response amplitude vs stimulus level in grams per millisecond) were fitted with the following power functions: $Y=0.202+0.358 X^{1.09}$ $\left(\right.$ Otof $\left.^{+/-}, R^{2}=0.56\right)$ and $Y=0.341+0.015 X^{4.11}\left(\right.$ Otof $\left.^{-1-}, R^{2}=0.32\right)$.

Table 1. Means and SDs for VsEP thresholds and response peak latencies and peakto-peak amplitudes at $+6 \mathrm{~dB}$ (re: $1.0 \mathrm{~g} / \mathrm{ms}$ )

\begin{tabular}{lcc}
\hline Response parameter & Heterozygotes $(+/-), n=11$ & Homozygotes $(-/-), n=9$ \\
\hline Threshold (dB, re: 1.0 & & \\
$\quad$ g/ms) & $-10.8 \pm 3.0$ & $-7.5 \pm 3.7$ \\
P1 latency (ms) & $1.37 \pm 0.07$ & $1.48 \pm 0.11$ \\
N1 latency (ms) & $1.68 \pm 0.08$ & $1.79 \pm 0.12$ \\
P2 latency (ms) & $2.13 \pm 0.10$ & $2.25 \pm 0.12$ \\
P1-N1 amplitude $(\mu \mathrm{V})$ & $0.98 \pm 0.30$ & $0.60 \pm 0.22$ \\
P2-N2 amplitude $(\mu \mathrm{V})$ & $1.05 \pm 0.43$ & $0.79 \pm 0.34$ \\
\hline
\end{tabular}

examine, in the cell-attached patch-clamp configuration, whether the pattern of spontaneous transmitter release is affected in the absence of otoferlin. Recordings were performed in intact utricles from P17-P27 mice in vitro. In Otof ${ }^{-1-}$ mice, spontane- ous firing activity was recorded, with a pattern of spikes (ranging from 8 to $30 \mathrm{~Hz}$ in frequency) similar to that of the wildtype mice (Fig. $2 A, B$ ). Indeed, the mean firing frequency and averaged coefficient of variation, an index of firing regularity, were not statistically different between mutant (Otof ${ }^{-1-}, n=8$ ) and wild-type $\left(\right.$ Otof $^{+/+}, n=13$ ) mice (Fig. 2C,D). The firing activity was blocked by the AMPA receptor antagonist NBQX (50 $\mu \mathrm{M} ; n=$ 3 ), indicating that it was driven by presynaptic glutamate release activating postsynaptic ionotropic glutamate receptors likely containing GluR2 and/or GluR3 AMPA receptor subunits (supplemental Fig. S2, available at www.jneurosci.org as supplemental material). The contribution of unconventional synaptic mechanisms (Goldberg, 1996), such as direct depolarization attributable to $\mathrm{K}^{+}$accumulation in the cleft of the calyx nerve endings, seems therefore limited in our in vitro conditions yet cannot be excluded in vivo. It is noteworthy that the block by the AMPA receptor antagonist proceeded very slowly and only after a period of 10-15 min perfusion, as reported in afferent fibers of the semicircular canal ampullar crista (Lee et al., 2005), which could reflect a poor access of the drug into the tight synaptic cleft of the calyx.

Spontaneous EPSCs were recorded at the calyx endings in the presence of TTX, which blocks action potential firing. No significant difference in the amplitude and frequency of EPSCs was found between wild-type $(21 \pm 9 \mathrm{pA} ; n=11)$ and Otof $^{-1-}(22 \pm 9 \mathrm{pA} ; n=12)$ mice (Fig. $2 E, F)$. Both monophasic and multiphasic EPSCs that are suggestive of multivesicular release (Glowatzki and Fuchs, 2002) were observed in wild-type and mutant calyx endings (Fig. 2G,H). Similar kinetics were observed in mutant and wild-type mice (mean rise time, $0.91 \pm 0.17$ vs $1.08 \pm 0.08 \mathrm{~ms}$; mean time constant decay, $4.9 \pm 1.8$ vs $6.1 \pm 1.3 \mathrm{~ms}$, respectively; not statistically different at $p>0.05$ in both cases). The amplitude histograms of EPSCs exhibited a skewed distribution with several discernable peaks, suggesting a multiquantal distribution and the possibility of coordinate release. A process of multivesicular release with perfect coordination would result in large-amplitude EPSCs. However, we cannot exclude that the multiphasic and large events could also arise from an overlapping activity of several ribbons or synapses. The single large afferent calyx fiber of type I hair cells receive inputs from several ribbons (release sites) and can also be dimorphic, i.e., connected to another hair cell with a calyx or a bouton ending. EPSCs amplitude distributions and interevent interval histograms were unchanged in Otof $^{-1}{ }^{-}$calyx endings (Fig. 2G-J). Therefore, the absence of otoferlin does not seem to affect spontaneous neurotransmitter release and the expres- 
sion of functional postsynaptic glutamate receptors at vestibular hair cell synapses.

$\mathrm{Ca}^{2+}$-dependent exocytosis is reduced in utricular hair cells lacking otoferlin Fusion of vesicles to the plasma membrane (exocytosis) was probed in hair cells of intact utricular organs by monitoring $C_{\mathrm{m}}$ in the whole-cell patch-clamp configuration using a lock-in amplifier. All experiments were performed on utricles dissected from $\mathrm{P} 4-\mathrm{P} 9$ mice, an age at which vestibular organs are functional and hair cells have nearly acquired their mature voltage-gated conductances (Rüsch et al., 1998). We used P4-P9 mice here because longer and more stable whole-cell patch recordings could be obtained at this age. $C_{\mathrm{m}}$ responses were evoked by depolarizing voltage steps that are known to activate L-type $\mathrm{Ca}^{2+}$ currents $\left(I_{\mathrm{Ca}}\right)$ in rodent vestibular hair cells (Bao et al., 2003; Almanza et al., 2003; Dou et al., 2004). To isolate $I_{\mathrm{Ca}}$ from other currents in the following experiments, we added $1 \mu \mathrm{M}$ TTX, $10 \mathrm{~mm}$ TEA, and $100 \mathrm{~nm}$ apamin to the extracellular solution and used a cesium chloride intracellular solution to block most of the outward potassium currents.

Exocytosis in type I hair cells displays faster kinetics and more efficient $\mathrm{Ca}^{2+}$ dependence than in type II hair cells Type I and type II hair cells from wild-type mice displayed rapidly activating, noninactivating, $\mathrm{Ca}^{2+}$ currents $\left(I_{\mathrm{Ca}}\right)$ in response to depolarizing voltage steps (Figs. 3, 4). In both cell types, analysis of the current-voltage relationship indicated that $I_{\mathrm{Ca}}$ activates near $-40 \mathrm{mV}$ and reaches a maximum near $-10 \mathrm{mV}$ (Fig. $4 D, H)$. Concomitant to $I_{\mathrm{Ca}}$ activation, a $C_{\mathrm{m}}$ increase $\left(\Delta C_{\mathrm{m}}\right)$ was recorded in $95 \%$ of the wild-type hair cells tested ( $n=45$ for type I and $n=16$ for type II hair cells), the amplitude of which varied with depolarizing step level and duration, as shown previously for cochlear hair cells (Johnson et al., 2005; Beurg et al., 2008). The voltage-activation curve of $\Delta C_{\mathrm{m}}$ displayed a bell shape that followed the $I_{\mathrm{Ca}}$ activation curve (Fig. 4C,D), consistent with $\Delta C_{\mathrm{m}}$ being activated consecutive to $\mathrm{Ca}^{2+}$ influx.

In type I hair cells, a $25 \mathrm{~ms}$ depolarization from -80 to -10 $\mathrm{mV}$ triggered an inward current $\left(I_{\mathrm{Ca}}\right)$ with a mean amplitude of $6.6 \pm 1.4 \mathrm{pA}(n=8)$ and a concomitant $C_{\mathrm{m}}$ jump averaging 5.5. $\pm 0.6 \mathrm{fF}$ in a perilymph-like extracellular solution containing $1.3 \mathrm{mM} \mathrm{Ca}^{2+}$ (Fig. $3 B$ ). Rising $\left[\mathrm{Ca}^{2+}\right]_{\text {ext }}$ to $5 \mathrm{~mm}$ resulted in an increased $I_{\mathrm{Ca}}$ amplitude with peak values of $29.0 \pm 3.1 \mathrm{pA}(n=$ 14) at $-10 \mathrm{mV}$ (Fig. 4D). In the same conditions in $5 \mathrm{~mm}$ $\left[\mathrm{Ca}^{2+}\right]_{\text {ext }}$, type II hair cells had a significant larger $I_{\mathrm{Ca}}$ of $58.2 \pm$ $5.0 \mathrm{pA}(n=9)$ (Fig. $4 E, H)$. Normalized to their respective membrane surface areas $\left(C_{\mathrm{m}}\right)$, type I and type II hair cells showed a
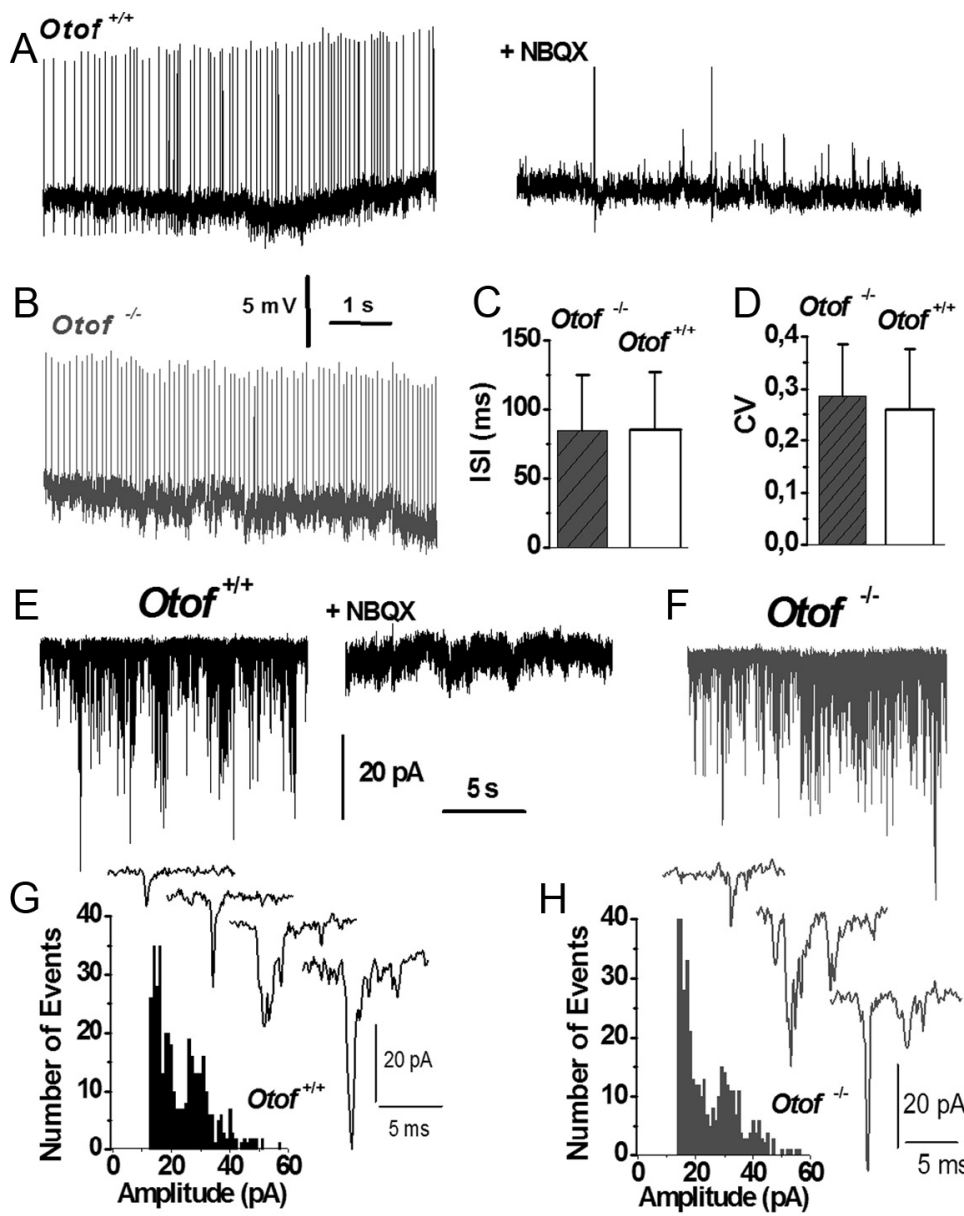

F Otof $^{\text {t. }}$

Figure 2. Postsynaptic recordings at the synaptic calyx ending of type I hair cells. $A-D$, Spontaneous action potential firing is unaffected in Otof ${ }^{-1}$ mice. Spontaneous firing activity was recorded in the intact mouse utricle (P17-P30) placed in artificial perilymph in vitro at $22^{\circ} \mathrm{C}$. Typical recordings from an 0 tof ${ }^{+/+}$calyx $(\boldsymbol{A})$ and an 0 tof ${ }^{-1-}$ calyx $(\boldsymbol{B})$ showing a spontaneous discharge rate of 12 and 14 spikes/s, respectively. The perfusion of $50 \mu \mathrm{MNBQX}$ blocked the firing activity ( $\boldsymbol{A}$, right). Interspike intervals (ISI; in $\boldsymbol{C}$ ) and coefficient of variation (CV; SD of interspike interval/mean spike interval; $\boldsymbol{D}$ ) are not significantly different between 0 tof $f^{+/+}$calyces $(n=13)$ and Otof ${ }^{-/-}$calyces $(n=8)$. E-J, Spontaneous EPSCs are normal in Otof ${ }^{-1-}$ mice. Spontaneous EPSCs were recorded in the intact mouse utricle (P17-P30) placed in artificial perilymph in vitro in the presence of $1 \mu \mathrm{M}$ TTX. Typical recordings in an $\mathrm{Otof}^{+/+}$calyx $(\boldsymbol{E})$ and an 0 tof ${ }^{-1-}$ calyx $(\boldsymbol{F})$ are shown. EPSC amplitude distributions $(\boldsymbol{G}, \boldsymbol{H})$ and interevent interval histograms $(\boldsymbol{I}, \boldsymbol{J})$ were not significantly different.

maximum $\mathrm{Ca}^{2+}$ current density of 7.9 and $14.9 \mathrm{pA} / \mathrm{pF}$, respectively. The $\Delta C_{\mathrm{m}}$ responses, for a $500 \mathrm{~ms}$ depolarization, were $17.5 \pm 2.4$ and $21.1 \pm 5.8 \mathrm{fF}$ in type I and type II hair cells, respectively (Fig. $4 C, G$ ). Therefore, the $\mathrm{Ca}^{2+}$ efficiency of exocytosis $\left(\Delta C_{\mathrm{m}} / I_{\mathrm{Ca}}\right)$ is higher in type I hair cells $(0.60 \mathrm{fF} / \mathrm{pA})$ than in type II hair cells $(0.36 \mathrm{fF} / \mathrm{pA})$.

Both $I_{\mathrm{Ca}}$ and $\Delta C_{\mathrm{m}}$ were reduced when adding $50 \mu \mathrm{M}$ nifedipine (reduction by $72 \pm 6$ and $93 \pm 3 \%$, respectively; $n=4$ ). These characteristics of $I_{\mathrm{Ca}}$ in type I and type II utricular hair cells are in good agreement with those described in the ampullar crista (Bao et al., 2003; Almanza et al., 2003; Dou et al., 2004). Together, our results suggest that vestibular hair cell exocytosis is activated 

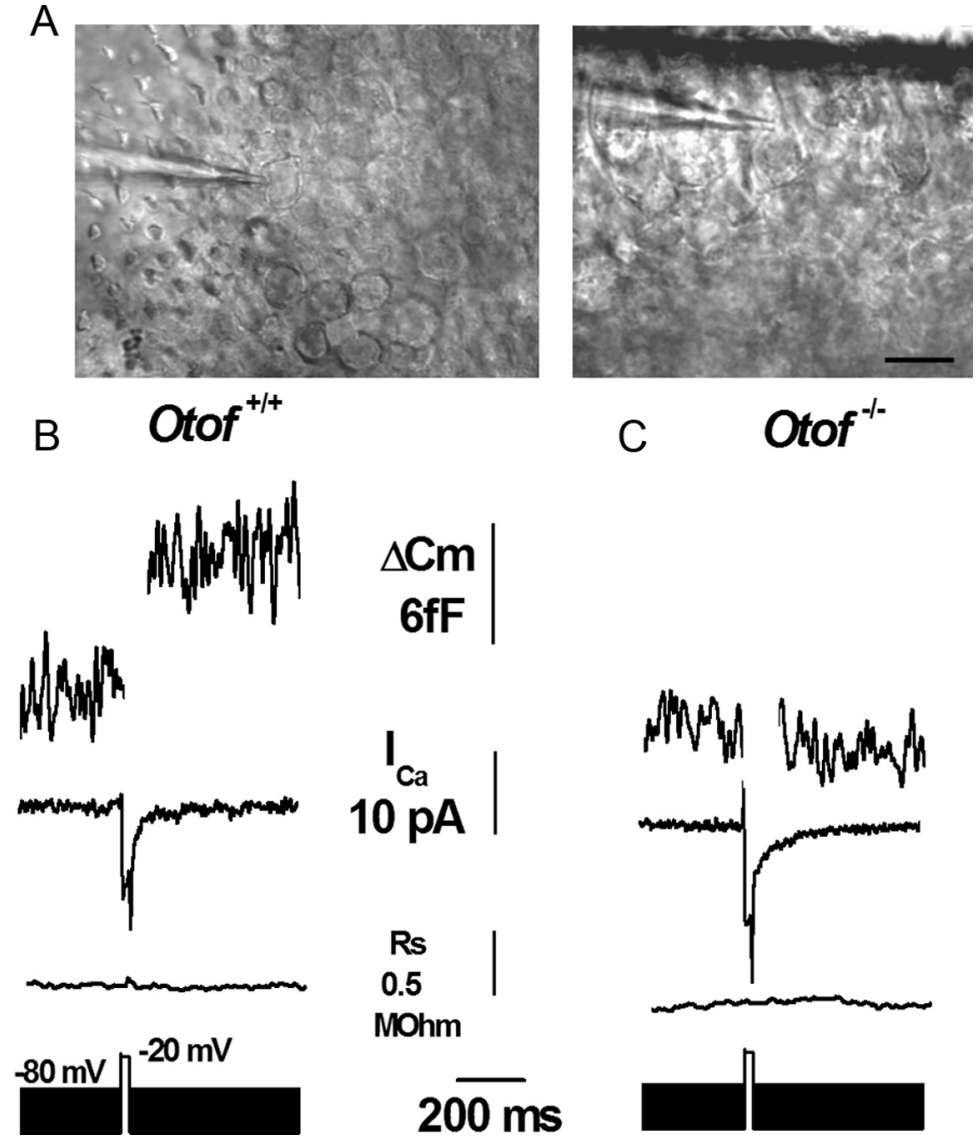

Figure 3. Fast $\mathrm{Ca}^{2+}$-dependent exocytosis is impaired in 0 tof ${ }^{-1-}$ type I hair cells. Changes in membrane capacitance $\left(\Delta C_{\mathrm{m}}\right)$ were recorded during voltage activation of $\mathrm{Ca}^{2+}$ current $\left(I_{\mathrm{Ca}}\right)$ in $\mathrm{P} 4-\mathrm{P} 9$ intact utricles bathed in artificial perilymph $\left(1.3 \mathrm{~mm} \mathrm{Ca}^{2+}\right)$ in vitro. In $\boldsymbol{A}$ are shown two differential interference contrast images of the intact utricle epithelium from which type I hair cells could be identified by their surrounding calyx. Most of the recorded cells were viewed from their apical surface as shown in the left. However, near the holding strand (black line above at right), which maintains and creases the utricle epithelium, the sensory hair cells could sometimes be seen from their side (right). Scale bar, $10 \mu \mathrm{m}$. A $25 \mathrm{~ms}$ voltage step (from -80 to $-20 \mathrm{mV}$ ) activated $I_{\mathrm{Ca}}$ and a $\Delta C_{\mathrm{m}}$ response in wild-type type I hair cells $(\boldsymbol{B})$. Although similar stimulation produced a normal $I_{\mathrm{Ca}}$ in Otof ${ }^{-1-}$ mice, the $\Delta C_{\mathrm{m}}$ response was absent $(\boldsymbol{C})$. The series resistance $\left(R_{\mathrm{s}}\right)$ was verified to be stable during the recordings.

by $\mathrm{Ca}^{2+}$ influx flowing through voltage-activated L-type $\mathrm{Ca}^{2+}$ channels. $\mathrm{Ca}^{2+}$ currents in vestibular hair cells, as in cochlear hair cells, do not display rapid time inactivation (Bao et al., 2003 and the present study). This unusual feature of $\mathrm{Ca}_{\mathrm{v}} 1.3 \mathrm{Ca}^{2+}$ channels has been proposed to depend on a regulation by a calmodulinlike $\mathrm{Ca}^{2+}$ binding protein, CaBP4 (Yang et al., 2006; Grant and Fuchs, 2008). This non-inactivating property of the $\mathrm{Ca}^{2+}$ current is certainly essential for the steadiness of transmitter release during constant stimulation of cochlear and vestibular hair cells.

To characterize the dynamics of vesicle pool recruitment, we used a single depolarizing step (from -80 to $-10 \mathrm{mV}$ ) with increasing duration from 10 to $3000 \mathrm{~ms}$ (in $5 \mathrm{~mm}$ extracellular $\mathrm{Ca}^{2+}$ to ease $I_{\mathrm{Ca}}$ measurement) (Fig. 5). The time-dependent change of $C_{\mathrm{m}}$ could be fitted by the sum of two exponential functions with time constants of 30 and $1031 \mathrm{~ms}$ in type I hair cells and 170 and $1291 \mathrm{~ms}$ in type II hair cells, respectively (Fig. 5). This may correspond to the existence of two synaptic pools: a readily releasable pool (RRP) that presumably arises from vesicles docked at the active zones, and a secondary releasable pool (SRP) that represents the release of vesicles located further from the $\mathrm{Ca}^{2+}$ channels. Using a value of $37 \mathrm{aF}$ per vesicle (Lenzi et al., 1999), a single-exponential fit to the first RRP phase (Fig. $5 A, B$, insets) gave a total release of 270 and 614 vesicles with release rates of $110 \pm 8 \mathrm{fF} / \mathrm{s}$ $(\sim 2970$ vesicles/s $)$ and $65 \pm 9 \mathrm{fF} / \mathrm{s}$ $(\sim 1756$ vesicles/s) in type I and type II hair cells, respectively.

To rule out any significant influence of endocytosis on the rates of exocytosis, the time course of endocytosis was evaluated after a $500 \mathrm{~ms}$ pulse depolarization from -80 to $-10 \mathrm{mV}$ by monitoring the subsequent $C_{\mathrm{m}}$ reduction (Fig. $6 \mathrm{~A}$ ). Endocytosis could be well approximated by a single-exponential function with an average time constant of $8.6 \pm 1.3 \mathrm{~s}(n=8)$. This time constant of endocytosis in vestibular hair cells is similar to values reported previously in auditory hair cells (Moser and Beutner, 2000; Schnee et al., 2005). The slow kinetics of endocytosis suggests that it contributes little to our $\Delta C_{\mathrm{m}}$ measurements for pulse depolarization durations below $3 \mathrm{~s}$.

The RRP and SRP per cell values found here are two to four times smaller than those reported in other hair cell types (Nouvian et al., 2006). This difference is presumably attributable to the small size of mouse utricular hair cells (with a mean surface membrane area corresponding to a $C_{\mathrm{m}}$ value of $\sim 4 \mathrm{fF}$; see Materials and Methods) and to the presence of fewer synaptic zones. Indeed, vestibular hair cells are approximately two times smaller than cochlear inner hair cells (mean $C_{\mathrm{m}}$ for inner hair cells of $\sim 8$ pF) (Moser and Beutner, 2000; Johnson et al., 2005) and approximately four times smaller than frog saccular hair cells (mean $C_{\mathrm{m}}$ of $15-16 \mathrm{pF}$ ) (Edmonds et al., 2004). If we assume a mean of seven to nine ribbons per vestibular hair cell (see our results below) compared with $\sim 15-20$ in apical inner hair cells (Meyer et al., 2009), we calculated a number of RRP synaptic vesicles per ribbon (SV/rib) of 30-38 in type I hair cells and 68-88 in type II hair cells. These numbers are comparable with those reported in mouse cochlear inner hair cells (24-64 SV/rib) (Johnson et al., 2005; Khimich et al., 2005).

$\mathrm{Ca}^{2+}$-dependent exocytosis is more severely affected in type I than in type II hair cells lacking otoferlin

Tested under similar conditions as wild-type hair cells, all Otof ${ }^{-1}$ type I hair cells $(n=26)$ showed a normal $I_{\mathrm{Ca}}$ (peak amplitude, $5.4 \pm 1.9$ and $32.5 \pm 5.8 \mathrm{pA}$ in 1.3 and $5 \mathrm{~mm}$ $\left[\mathrm{Ca}^{2+}\right]_{\text {ext }}$, respectively) but no significant $\Delta C_{\mathrm{m}}$ responses (below background threshold of $0.5 \mathrm{fF}$ ) when depolarized from -80 to $-10 \mathrm{mV}$ for $10 \mathrm{~ms}$ up to $200 \mathrm{~ms}$ (Fig. $3 C$ ). The $\Delta C_{\mathrm{m}}$ response was markedly reduced to $1.1 \pm 0.5 \mathrm{fF}(n=13)$ during a $500 \mathrm{~ms}$ depolarization at the voltage value corresponding to peak $I_{\mathrm{Ca}}$ (Fig. $4 B, C$ ). The first kinetic component of the $\Delta C_{\mathrm{m}}$ response, corresponding to the RRP, was abolished in both $1.3 \mathrm{~mm}$ (Fig. $3 C$ ) and $5 \mathrm{~mm}\left[\mathrm{Ca}^{2+}\right]_{\mathrm{ext}}$ conditions (Fig. $5 \mathrm{~A}$, inset), whereas the second kinetic component of exocytosis, corresponding to the 


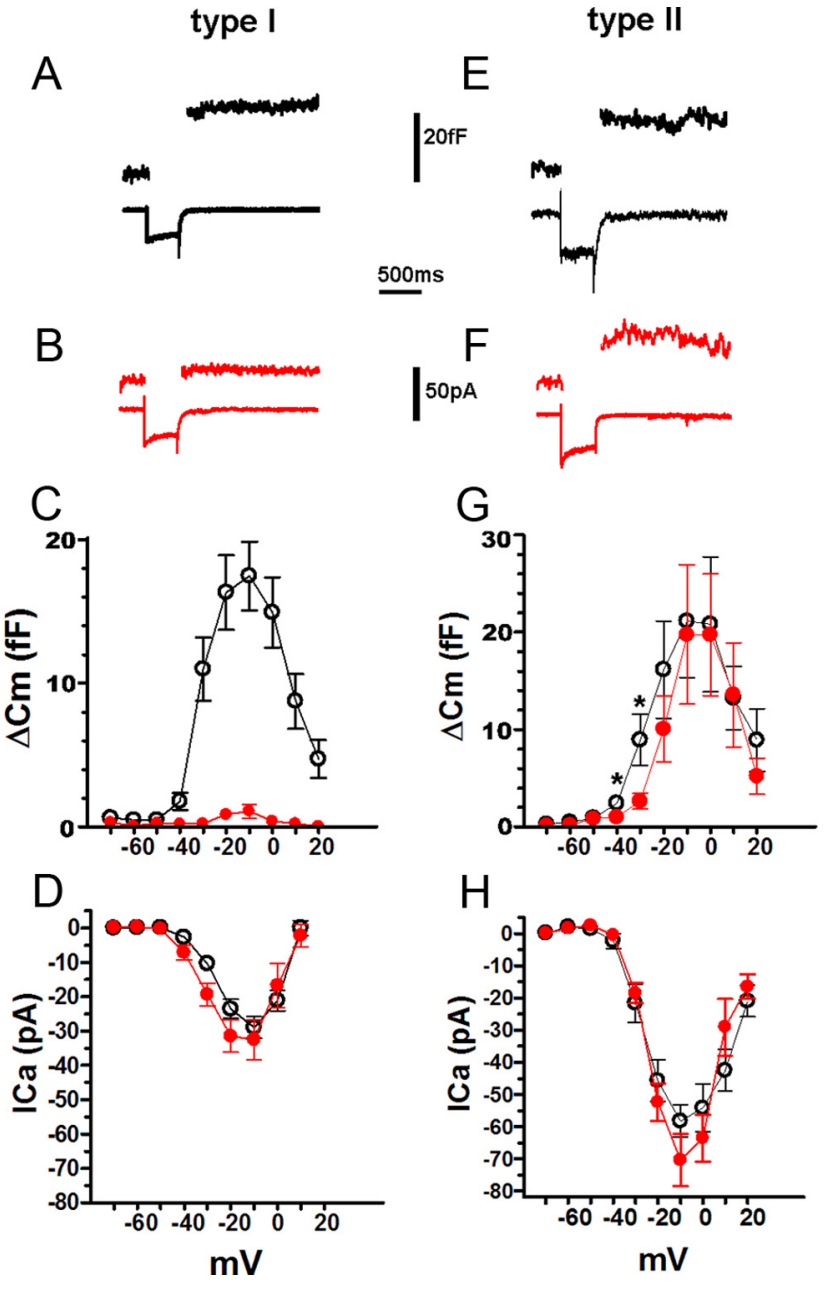

Figure 4. $\quad \mathrm{Ca}^{2+}$-dependent exocytosis in type I $(\boldsymbol{A}-\boldsymbol{D})$ and type II hair cells $(\boldsymbol{E}-\boldsymbol{G})$. Example of $I_{\mathrm{Ca}}$ voltage activation (bottom trace) triggering a concomitant jump in membrane capacitance $\left(\Delta C_{m}\right)$ in a wild-type type $I$ hair cell $(A)$. The cell was held at $-80 \mathrm{mV}$ and stepped for 500 $\mathrm{ms}$ to $-10 \mathrm{mV}$. Utricles were bathed in artificial perilymph with $5 \mathrm{~mm}\left[\mathrm{Ca}^{2+}\right]_{\text {ext }}$. Stimulated under similar condition, whereas $I_{C a}$ was essentially unchanged, 0 tof $^{-1-}$ type I hair cells display a primarily reduced $\Delta C_{m}$ response $(B)$. Voltage-activation curve of $I_{C_{a}}(D)$ and corresponding $\Delta C_{\mathrm{m}}$ responses $(C)$ in wild-type (open black circle; $n=14$ ) and 0 tof ${ }^{-1-}$ (red filled circle; $n=13$ ) type I hair cells. Each voltage step was separated by 1 min to allow recovery. Note the large inhibition of the $\Delta C_{\mathrm{m}}$ in 0 tof $^{-1}$ mice, whereas $I_{\mathrm{ca}}$ was essentially unaffected. Example of $I_{\mathrm{Ca}}$ and $\Delta C_{\mathrm{m}}$ responses in a wild-type $(\boldsymbol{E})$ and $0 \operatorname{tof}^{-1-}(\boldsymbol{F})$ type II hair cell recorded in similar conditions than for type I hair cells. Voltage-activation curved of $I_{\mathrm{Ca}}(\boldsymbol{H})$ and corresponding $\Delta C_{\mathrm{m}}$ (G) in wild-type (black open circle; $n=9$ ) and in Otof ${ }^{-1-}$ (red filled circles; $\left.n=17\right)$. Note that $\Delta C_{\mathrm{m}}$ were not significantly affected in 0 tof $^{-1-}$ type II hair cells at $I_{\text {Ca }}$ peak. However, at -40 and $-30 \mathrm{mV}$, near the activation voltage threshold of $I_{\mathrm{Ca}^{\prime}} \Delta C_{\mathrm{m}}$ were significantly lower in mutant mice (asterisks). This indicated a slight decrease in $\mathrm{Ca}^{2+}$ efficiency of exocytosis in type II hair cells.

SRP, persisted but with a significant large time constant of 2042 ms (Fig. 5A)

The defective exocytosis in the mutant type I hair cells could not be attributed to changes in the properties of the $\mathrm{Ca}^{2+}$ currents. Indeed, analysis of normalized conductance-voltage curves gave indistinguishable parameters $G_{\max }$ (maximum conductance), $V_{1 / 2}$ (potential giving half-activation), and $S$ (slope) when fitted with a first-order Boltzmann equation, in wild-type $\left(n=17\right.$ cells; in $5 \mathrm{mM}\left[\mathrm{Ca}^{2+}\right]_{\text {ext }} ; G_{\max }=1.04 \pm 0.16 \mathrm{nS} ; V_{1 / 2}=$ $-26.34 \pm 0.55 \mathrm{mV} ; S=7.04 \pm 0.50 \mathrm{mV})$ and Otof $^{-1-}(n=19$ cells; in $5 \mathrm{mM}\left[\mathrm{Ca}^{2+}\right]_{\mathrm{ext}} ; G_{\max }=1.21 \pm 0.04 \mathrm{nS} ; V_{1 / 2}=-27.46 \pm$ $1.00 \mathrm{mV} ; S=7.18 \pm 0.91 \mathrm{mV}$ ) cells. Furthermore, the time constants of $I_{\mathrm{Ca}}$ activation were similar in wild-type and Otof ${ }^{-/-}$
A type I hair cells

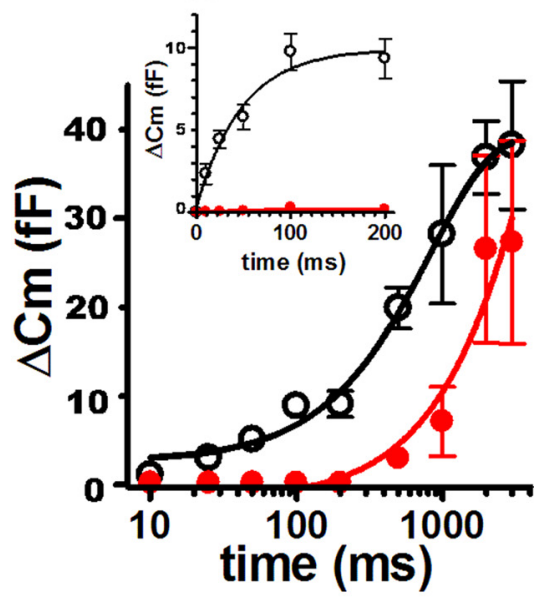

B

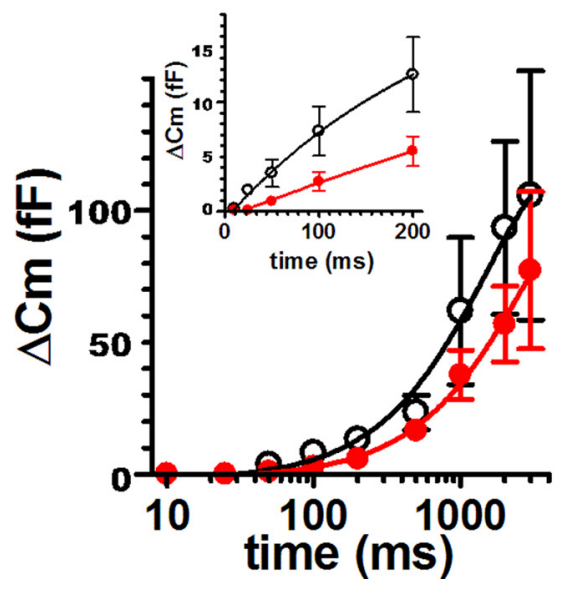

Figure 5. Kinetics of vesicular release. $A$, Type I hair cells exocytosis $\left(\Delta C_{m}\right)$ in responses to voltage steps of increasing duration. Hair cells were stimulated with the same voltage step from -80 to $-10 \mathrm{mV}$ in artificial perilymph containing $5 \mathrm{~mm}\left[\mathrm{Ca}^{2+}\right]_{\text {ext }}$. Each step was separated by $1 \mathrm{~min}$. A first phase of exocytosis during short stimuli ranging from 10 to $200 \mathrm{~ms}$ recruited an initial small $\Delta C_{m}$ component that likely represents the RRP of vesicles docked at the active zones (inset). In wild-type hair cells (open black circles; $n=17$ ), data were best fitted using a singleexponential function with $\tau=34 \mathrm{~ms}$ and maximum of $9.9 \mathrm{fF}$. Note that 0 tof ${ }^{-1-}$ hair cells tested in similar conditions did not show significant $\Delta C_{m}$ responses (filled red circle; $n=19$ ). In wild-type hair cells (open black circles; $n=15$ ), the $\Delta C_{\mathrm{m}}$ variation between stimuli ranging from 10 to $3000 \mathrm{~ms}$ could be fitted with the sum of two exponentials $\left(\tau_{1}=30 \mathrm{~ms}\right.$ and $\tau_{2}=$ $1031 \mathrm{~ms}$, with a maximum $\Delta C_{\mathrm{m}}$ of $37.2 \mathrm{fF}$ ). In 0 tof ${ }^{-1-}$ hair cells (filled red circles; $n=14$ ), data were fitted with a single exponential $(\tau=2042 \mathrm{~ms})$. $\boldsymbol{B}$, In type II hair cells, in similar experimental conditions, $\Delta C_{m}$ kinetics in wild-type cells (open black circles; $n=9$ ) could also be fitted by the sum of two exponentials $\left(\tau_{1}=170 \mathrm{~ms}\right.$ and $\tau_{2}=1291 \mathrm{~ms}$ ). In 0 tof ${ }^{-1}$ type ll hair cells (filled red circles; $n=14$ ), the initial phase of the RRP (up to $200 \mathrm{~ms}$ ) was significantly reduced (inset), whereas the SRP was essentially unaffected.

hair cells (for a step from -80 to $-10 \mathrm{mV} ; \tau=0.42 \pm 0.03$ and $0.45 \pm 0.05 \mathrm{~ms}$, respectively). Finally, $I_{\mathrm{Ca}}$ showed similar low inactivation, with a mean reduction of $7.5 \pm 2.5$ and $6.7 \pm 3.3 \%$ over a $500 \mathrm{~ms}$ voltage step from -80 to $-10 \mathrm{mV}$ in wild-type and Otof ${ }^{-1-}$ hair cells, respectively.

Tested under similar conditions, type II hair cells from Otof ${ }^{-1}$ mice displayed $I_{\mathrm{Ca}}(70.3 \pm 8.1 \mathrm{pA})$ and $\Delta C_{\mathrm{m}}$ responses $(19.8 \pm 7.2 \mathrm{fF})$ that were not significantly different from wildtype II hair cells when stepping the cells from -80 to $-10 \mathrm{mV}$ for $500 \mathrm{~ms}(n=17)$ (Fig. $4 F-H)$. However, the $C_{\mathrm{m}}$-voltage activation curve in mutant mice showed significant lower $C_{\mathrm{m}}$ responses for small depolarizations at -40 and $-30 \mathrm{mV}$, that is when $I_{\mathrm{Ca}}$ is 
A
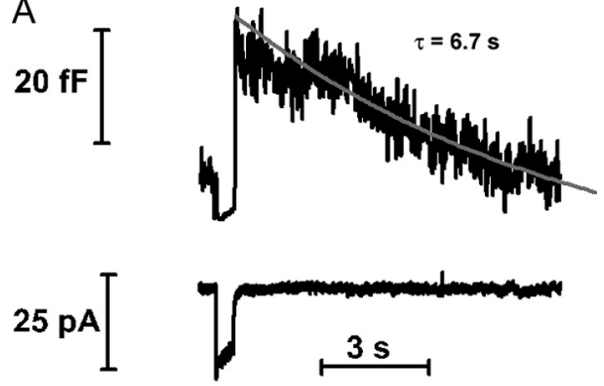

B

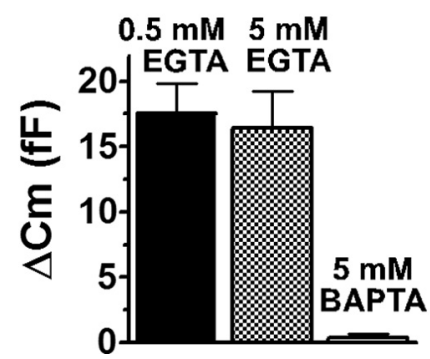

Figure 6. Kinetics of endocytosis $(\boldsymbol{A})$ and sensitivity of exocytosis to internal $\mathrm{Ca}^{2+}$ buffering (B). $\boldsymbol{A}$, Example of endocytosis measured in a type I hair cell: an increase in $C_{m}$ (exocytosis) was triggered by a $500 \mathrm{~ms}$ pulse (from -80 to $-10 \mathrm{mV}$ in $5 \mathrm{~mm}\left[\mathrm{Ca}^{2+}\right]_{\text {ext }}$ ), and the time course of $C_{m}$ decrease was monitored over a period of $20 \mathrm{~s}$. Endocytosis was best fitted using a single exponential with $\tau=6.7 \mathrm{~s}$ (gray line). $B$, Exocytosis in type I hair cells was recorded in different intracellular $\mathrm{Ca}^{2+}$ buffering conditions: EGTA at $0.5 \mathrm{~mm}(n=15)$, EGTA at $5 \mathrm{~mm}(n=5)$, and BAPTA at $5 \mathrm{~mm}(n=4) . \Delta C_{\mathrm{m}}$ responses were evoked by a $500 \mathrm{~ms}$ pulse (from -80 to $-10 \mathrm{mV}$ ) in $5 \mathrm{~mm}\left[\mathrm{Ca}^{2+}\right]_{\mathrm{ext}}$.

small (Fig. $4 G)(p<0.05)$, indicating that the $\mathrm{Ca}^{2+}$-dependent exocytotic process is also affected in type II hair cells lacking otoferlin. The release rate of the RRP component of the $C_{\mathrm{m}}$ response was indeed significantly reduced to a maximum initial release of $34 \pm 9 \mathrm{fF} / \mathrm{s}$, a value approximately two times lower than in wild-type cells (Fig. $5 B$, inset). In contrast, the release rate of the SRP was not significantly affected (Fig. 5B). Again, type II hair cells lacking otoferlin showed normal $I_{\mathrm{Ca}}$. Indeed, normalized conductance-voltage curves gave indistinguishable parameters $\left(G_{\max }, V_{1 / 2}\right.$, and $S ; p>0.05$ ) between wild-type ( $n=9$ cells; in 5 $\mathrm{mm}\left[\mathrm{Ca}^{2+}\right]_{\text {ext }} ; G_{\max }=2.17 \pm 0.13 \mathrm{nS} ; V_{1 / 2}=-26.79 \pm 0.69 \mathrm{mV}$; $S=6.15 \pm 0.61 \mathrm{mV})$ and $\mathrm{Otof}^{-1}(n=14$ cells; in $5 \mathrm{~mm}$ $\left[\mathrm{Ca}^{2+}\right]_{\mathrm{ext}} ; G_{\max }=2.59 \pm 0.45 \mathrm{nS} ; V_{1 / 2}=-23.49 \pm 1.88 \mathrm{mV} ; S=$ $5.25 \pm 1.62 \mathrm{mV}$ ) cells when fitted with a first-order Boltzmann equation. Furthermore, the time constants of $I_{\mathrm{Ca}}$ activation were similar in wild-type and $\mathrm{Otof}^{-1-}$ type II hair cells $(-10 \mathrm{mV} ; \tau=$ $0.54 \pm 0.05 \mathrm{~s}$ and $0.56 \pm 0.09 \mathrm{~ms}$, respectively). Finally, $I_{\mathrm{Ca}}$ showed similar low inactivation, with a reduction of $9.1 \pm 2.3$ and $9.9 \pm 4.0 \%$ over a $500 \mathrm{~ms}$ step from -80 to $-10 \mathrm{mV}$ in wild-type and $\mathrm{Otof}^{-1-}$ hair cells, respectively.

The linear $\mathrm{Ca}^{2+}$ dependence of exocytosis is affected in type I and type II hair cells lacking otoferlin

Next, we examined the relationship between $\mathrm{Ca}^{2+}$ entry and RRP exocytosis by depolarizing the vestibular hair cells for different duration, changing $\left[\mathrm{Ca}^{2+}\right]_{\text {ext }}$ or stepping to different test potentials. These different protocols have been designed to probe the organization of the release sites and $\mathrm{Ca}^{2+}$ channels $\left(\mathrm{Ca}^{2+}\right.$ domains) at the synaptic zones. Exocytosis, driven by nonoverlapping $\mathrm{Ca}^{2+}$ nanodomains (a single channel is thought to be sufficient to activate release of a nearby vesicle), would change linearly when primarily manipulating the number of open channels and nonlinearly when varying the single-channel current as in cochlear inner hair cells (Brandt et al., 2005). In contrast, an organization of synaptic $\mathrm{Ca}^{2+}$ domains that involves an overlapping population-based $\mathrm{Ca}^{2+}$ channels such as proposed in frog saccular hair cells (Roberts et al., 1990; Roberts, 1994) predicts that changes in the number of open channels or in the $\mathrm{Ca}^{2+}$ flux per channel would produce exocytosis with a similar linear dependence on $\mathrm{Ca}^{2+}$ (Augustine et al., 2003).

Linear dependence on $\mathrm{I}_{C a}$ charge integral during cumulative $\mathrm{Ca}^{2+}$ entry. The relationship between RRP exocytosis and $\mathrm{Ca}^{2+}$ entry was first evaluated in wild-type type I and type II hair cells by plotting $\Delta C_{\mathrm{m}}$ response against $I_{\mathrm{Ca}}$ charge integral $\left(Q_{\mathrm{Ca}}=I_{\mathrm{Ca}} \times\right.$ t) during a constant depolarizing step from -80 to $-10 \mathrm{mV}$, with increasing time durations $(t)$ from 10 to $200 \mathrm{~ms}$ in $5 \mathrm{~mm}$ $\left[\mathrm{Ca}^{2+}\right]_{\text {ext }}\left(I_{\mathrm{Ca}}\right.$ from cells described in Fig. $\left.5 \mathrm{~A}\right)$. This protocol tests the intrinsic $\mathrm{Ca}^{2+}$ sensitivity of the synaptic machinery independently of the respective contributions of the number of open channels and $\mathrm{Ca}^{2+}$ flux per channel. Considering that vesicle fusion $\left(\Delta C_{\mathrm{m}}\right)$ is proportional to the $n$th power of $\mathrm{Ca}^{2+}$ activity at release sites (Zucker and Fogelson, 1986), data were fitted by the equation $\Delta C_{\mathrm{m}}=g\left[Q_{\mathrm{Ca}}\right]^{N}$ with $N=0.72 \pm 0.02$ (slope factor, $g=$ $\left.4.56 \mathrm{fF} / \mathrm{pC} ; R^{2}=0.97\right)$ and $N=0.90 \pm 0.02(g=1.40 \mathrm{fF} / \mathrm{pC}$; $\left.R^{2}=0.99\right)$ in type I and type II hair cells, respectively, indicating an almost linear relationship between cumulative $\mathrm{Ca}^{2+}$ entry and exocytosis in both cell types and a more efficient process in type I hair cells (Fig. $7 A, D$ ). An $N$ value of 0.72 indicates that the fitting curve is somewhat "convex," which is likely attributable to the fact that, near the final $Q_{\mathrm{Ca}}$ range, exocytosis almost reaches saturation in type I hair cells (Fig. $5 \mathrm{~A}$, inset). Our results thus suggest that the amount of exocytosis is a linear function of cumulative $\mathrm{Ca}^{2+}$ entry at the active zone both in type I and type II hair cells. This conclusion is compatible with the $\mathrm{Ca}^{2+}$ "shell domain" model in which diffusion of $\mathrm{Ca}^{2+}$ ions and intracellular $\mathrm{Ca}^{2+}$ buffers near the membrane are not free at the release site, then allowing saturation of the sensor and a linear increase of exocytosis with depolarization duration (Roberts 1994; Kits et al., 1999; Mansvelder and Kits, 2000).

In $\mathrm{Otof}^{-1-}$ utricles, using a similar protocol, RRP exocytosis was completely abolished in type I hair cells (Figs. $5 A, 7 A$, red symbols) and only partially reduced in type II hair cells (Fig. 7D). In $\mathrm{Otof}^{-1-}$ type II hair cells, data were best fitted by using a power function with $N=1.71 \pm 0.03$ and a reduced slope factor $g=$ $0.07 \pm 0.01 \mathrm{fF} / \mathrm{pC}$ (Fig. $7 D$ ). Remarkably, RRP exocytosis in Otof $^{-1}$ type I hair cells could be partially rescued when increasing $\left[\mathrm{Ca}^{2+}\right]_{\text {ext }}$ from 5 to $10 \mathrm{~mm}$ (Fig. $6 \mathrm{~A}$, green symbols). Data were then fitted using a power function with $N=2.20 \pm 0.10$ and a reduced slope factor $g=0.02 \pm 0.004 \mathrm{fF} / \mathrm{pC}$ (Fig. 7A). These results suggest that either the $\mathrm{Ca}^{2+}$ affinity of the synaptic machinery is markedly decreased or the free diffusion of $\mathrm{Ca}^{2+}$ ions at the release sites is modified in such a way that the sensor is no longer saturated.

Linear dependence on $\mathrm{I}_{\mathrm{Ca}}$ amplitude when varying the number of open channels and the $\mathrm{Ca}^{2+}$ flux per channel. To further investigate the $\mathrm{Ca}^{2+}$ dependence of exocytosis in type I and type II hair cells, independently of stimulus duration, $\Delta C_{\mathrm{m}}$ responses were plotted against $I_{\mathrm{Ca}}$ peak amplitude for a constant $500 \mathrm{~ms}$ voltage step at different membrane potentials from $-80 \mathrm{mV}$, in constant $5 \mathrm{~mm}\left[\mathrm{Ca}^{2+}\right]_{\text {ext }}$ (Fig. $\left.7 B, E, F\right)$. To avoid underestimation of $\mathrm{Ca}^{2+}$ entry $\left(Q_{\mathrm{Ca}}\right)$ by unblocked outward $\mathrm{K}^{+}$current at large depolarizing potentials, exocytosis was here plotted against $I_{\mathrm{Ca}}$ peak amplitude. Data were again fitted by using a power function $\Delta C_{\mathrm{m}}=g\left[I_{\mathrm{Ca}}\right]^{N}$, with $I_{\mathrm{Ca}}$ varying primarily as a function of open $\mathrm{Ca}^{2+}$ channels (number increasing with depolarization up to a maximum at $-10 \mathrm{mV}$ ). Data were best fitted by 

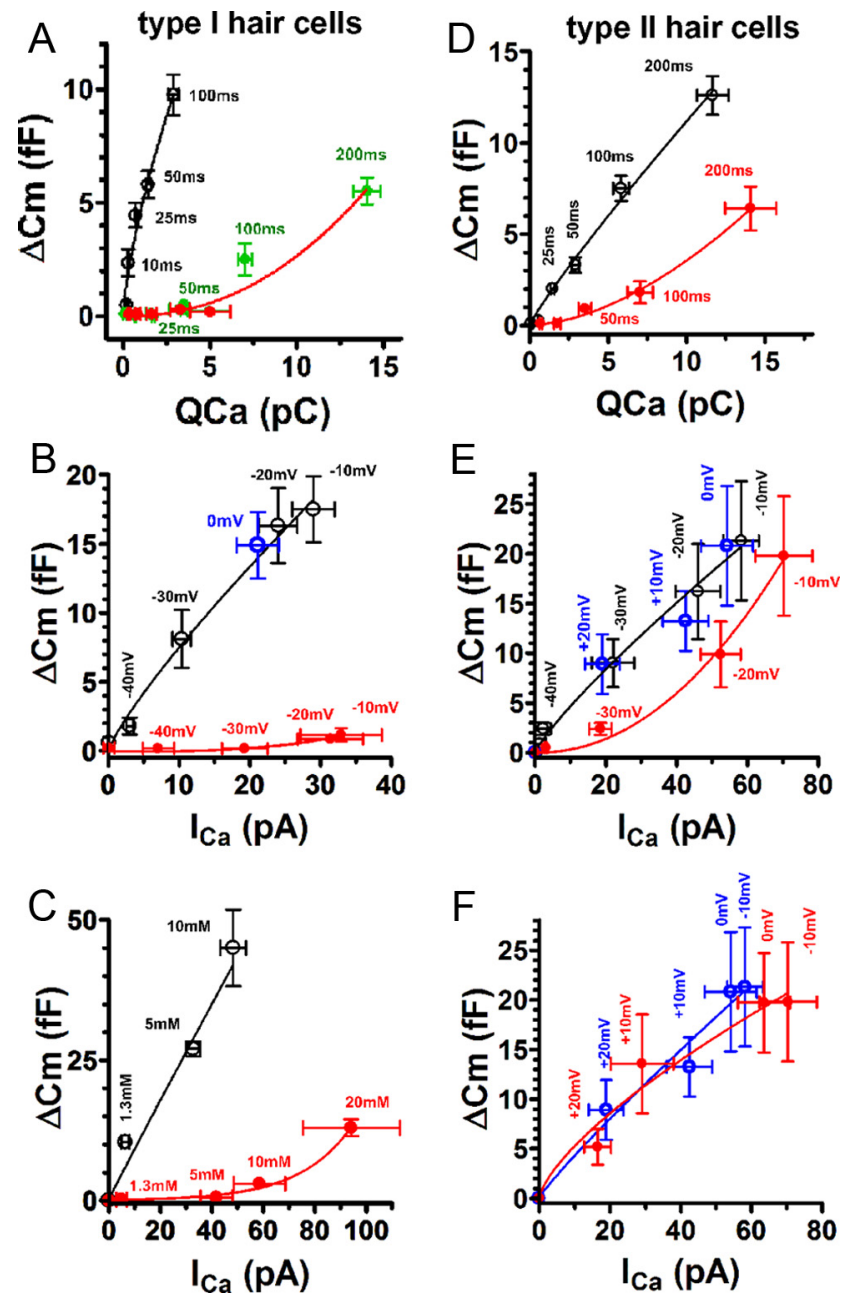

Figure 7. The synaptic transfer function $\left(\Delta C_{\mathrm{m}} / I_{\mathrm{Ca}}\right)$ becomes less efficient and nonlinear in vestibular hair cells lacking otoferlin. $A, D$, Exocytosis as a power function of integrated $\mathrm{Ca}^{2+}$ entry when varying pulse duration $(10,25,50,100$, and $200 \mathrm{~ms})$ in type $I(\boldsymbol{A})$ and type II (D) hair cells. Data were fit by the equation $\Delta C_{\mathrm{m}}=g\left[\mathrm{Q}_{\mathrm{C}_{\mathrm{a}}}\right]^{N}$ with $N=0.72 \pm 0.02$ (slope efficiency, $g=4.56 \mathrm{fF} / \mathrm{pC})$ and $N=0.90 \pm 0.02(g=1.40)$ in wild-type type I $(A$, black open circles; $n=$ 17) and type II ( $\boldsymbol{D}$, black open circles; $n=9$ ) hair cells, respectively. In Otof ${ }^{-1-}$ hair cells, data were fit with a nonlinear power function with $N=2.2 \pm 0.10(g=0.02 \pm 0.004)$ and $N=$ $1.71 \pm 0.03(g=0.07 \pm 0.01)$ in type I $(\boldsymbol{A})$ and type II ( $\boldsymbol{D}$; red filled circles; $n=14)$, respectively. In type I 0 tof $^{-1}$ hair cells ( $\boldsymbol{A}$, red line), $\Delta C_{\mathrm{m}}$ responses are recorded in $5 \mathrm{~mm}$ $\left[\mathrm{Ca}^{2+}\right]_{\text {ext }}$ (red symbols; $\left.n=19\right)$ and in $10 \mathrm{~mm}\left[\mathrm{Ca}^{2+}\right]_{\text {ext }}$ (green symbols; $\left.n=5\right) . \boldsymbol{B}, \boldsymbol{E}$, Synaptic transfer function when varying test potentials in type $I(\boldsymbol{B})$ and type $I I(\boldsymbol{E}, \boldsymbol{F})$ hair cells. $I_{\mathrm{Ca}}$ and corresponding $\Delta C_{m}$ responses were recorded at different membrane potentials $(500 \mathrm{~ms}$ voltage step from $-80 \mathrm{mV}$ in $10 \mathrm{mV}$ increments) in $5 \mathrm{~mm}\left[\mathrm{Ca}^{2+}\right]_{\text {ext }}$. Solid lines are fits to data points according to a power function $\Delta C_{m}=g\left[I_{\mathrm{C}}\right]^{N}$ with $N=0.83 \pm 0.08(g=1.10 \pm 0.30 \mathrm{fF} / \mathrm{pA})$ and $N=0.85 \pm 0.08(g=0.66 \pm 0.19 \mathrm{fF} / \mathrm{pA})$ in wild-type type I ( $\boldsymbol{B}$, black open circles and blue open circle at $0 \mathrm{mV} ; n=14$ ) and type II ( $\boldsymbol{E}$, black open circles from -80 to $-10 \mathrm{mV}$ and blue open circles from 0 to $+20 \mathrm{mV} ; n=8$ ) hair cells, respectively. In 0 tof $^{-1-}$ hair cells (red filled circles), data were fitted using a nonlinear power function with $N=3.22 \pm 0.71$ ( $g=$ $\left.1.48 .10^{-5} \pm 0.90 .10^{-5} \mathrm{fF} / \mathrm{pA} ; n=13\right)$ and $N=2.10 \pm 0.20(g=0.003 \pm 0.001 \mathrm{fF} / \mathrm{pA}$; $n=17$ ) in type I and type II hair cells, respectively. $F$, Synaptic transfer function in type II hair cells when plotting $\Delta C_{\mathrm{m}}$ against $\mathrm{I}_{\mathrm{Ca}}$ at positive potentials between -10 to $+20 \mathrm{mV}$ (from the same cells shown in $\boldsymbol{E}$ ): data were fitted with a power function with $N=0.90 \pm 0.16$ ( $g=$ $0.45 \pm 0.28 \mathrm{fF} / \mathrm{pA}$; red line) in $\mathrm{Otof}^{-1}$ type ll hair cells that was not significantly different from wild-type with $N=0.80 \pm 0.24$ ( $g=0.79 \pm 0.20$; blue line). C, Synaptic transfer function in type I hair cells when varying $\left[\mathrm{Ca}^{2+}\right]_{\text {ext }} \cdot l_{\mathrm{Ca}}$ and corresponding $\Delta C_{\mathrm{m}}$ responses were obtained from a single $500 \mathrm{~ms}$ voltage step from -80 to $-10 \mathrm{mV}$ in different extracellular $\mathrm{Ca}^{2+}$ concentrations: $0,1.3,5,10$, and $20 \mathrm{~mm}$ in 0 tof ${ }^{-1-}$ hair cells (red filled circles) and $0,1.3,5$, and 10 $\mathrm{mm}$ in wild-type hair cells (black open circles). Each $\Delta C_{\mathrm{m}}$ and $I_{\text {Ca }}$ values are means from 5 to 22 hair cells. Solid lines are fits to data points according to a power function with $N=0.97 \pm 0.05$ $(g=0.95 \pm 0.20 \mathrm{fF} / \mathrm{pA})$ and $N=3.38 \pm 0.06\left(g=2.8010^{-6} \pm 0.7010^{-6} \mathrm{fF} / \mathrm{pA}\right)$ in wild-type and 0 tof $^{-1-}$ type I hair cells, respectively. a power function with $N=0.83 \pm 0.08(g=1.10 \pm 0.30 \mathrm{fF} / \mathrm{pA})$ and $N=0.85 \pm 0.08(g=0.66 \pm 0.19 \mathrm{fF} / \mathrm{pA})$ in type $\mathrm{I}$ and type II hair cells, respectively (Fig. $7 B, E$ ), indicating a linear relationship between $\mathrm{Ca}^{2+}$ entry and exocytosis when increasing the number of open $\mathrm{Ca}^{2+}$ channels.

The relationship between $I_{\mathrm{Ca}}$ and $\Delta C_{\mathrm{m}}$ was next examined when primarily manipulating the $\mathrm{Ca}^{2+}$ flux per channel. Although this relationship could not be examined at positive potentials in type I hair cells because $I_{\mathrm{Ca}}$ was obscured above $0 \mathrm{mV}$ by the presence of an outward current (likely $\mathrm{Cs}^{+}$flowing through $g_{\mathrm{KL}}$ ) (Rüsch et al., 1998), we found that $\Delta C_{\mathrm{m}}$ and $I_{\mathrm{Ca}}$ maintained a similar linear relationship between -10 and $0 \mathrm{mV}$. At these potentials, the number of open $\mathrm{Ca}^{2+}$ channels is constant and maximum; $I_{\mathrm{Ca}}$ thus mainly reflects $\mathrm{Ca}^{2+}$ flux per channel that depends on the driving force (Fig. $7 B$, blue circle). To overcome the problem of the outward current at positive potentials, the relationship between $\Delta C_{\mathrm{m}}$ and $\mathrm{Ca}^{2+}$ flux per channel was further examined in type I hair cells by using different $\left[\mathrm{Ca}^{2+}\right]_{\text {ext }}(0,1.3,5$, and $10 \mathrm{mM})$ at constant and maximal voltage activation of $\mathrm{Ca}^{2+}$ channels $(-10 \mathrm{mV})$ from a holding potential of $-80 \mathrm{mV}$, for a $500 \mathrm{~ms}$ duration. Data were again approximated using a power function $\Delta C_{\mathrm{m}}=g\left[I_{\mathrm{Ca}}\right]^{N}$, with $I_{\mathrm{Ca}}$ varying only as a function of the $\mathrm{Ca}^{2+}$ flux per channel at constant open channel probability. Using this protocol, the $\mathrm{Ca}^{2+}$ dependence of exocytosis showed again a linear relationship. Indeed, data were best fitted using a power function with $N=0.97 \pm 0.05$ and a slope factor $g=0.95 \pm 0.20 \mathrm{fF} / \mathrm{pA}$ (Fig. 7C). Notably, a similar linear relationship was obtained when using shorter pulse durations of 50 or $100 \mathrm{~ms}$ (data not shown).

In type II hair cells, the $\mathrm{Ca}^{2+}$ dependence of $\Delta C_{\mathrm{m}}$ could be studied at positive potentials with no apparent outward contaminating current up to $+20 \mathrm{mV}$. As in type I hair cells, $\Delta C_{\mathrm{m}}$ showed a linear relationship with $I_{\mathrm{Ca}}$ both for small depolarizations (the driving force for $\mathrm{Ca}^{2+}$ entry is large, whereas only few channels are opened) (Fig. 7E, black circles) and large depolarizations (the number of open channels is maximum above $-10 \mathrm{mV}$, but the $\mathrm{Ca}^{2+}$ flux per channel decreases as the voltage increases) (Fig. $7 E$, blue circles).

Together, these results suggest that exocytosis in type I and type II hair cells is proportional to total $\mathrm{Ca}^{2+}$ entry, whatever the number of open channels and the $\mathrm{Ca}^{2+}$ flux per channel. This situation seems not to be compatible with an organization of independent $\mathrm{Ca}^{2+}$ nanodomains as proposed in cochlear inner hair cells, in which a change in the $\mathrm{Ca}^{2+}$ flux per channel is nonlinearly related to the $\Delta C_{\mathrm{m}}$ response (Brandt et al., 2005). Our data rather indicate a situation similar to the one described in frog saccular hair cells, in which it has been suggested that tens of $\mathrm{Ca}^{2+}$ channels cooperate in a large " $\mathrm{Ca}^{2+}$ domain" at each synaptic active zone (Roberts et al., 1990; Roberts, 1994).

Using a similar test potential, when primarily varying the number of open channels, data points in mutant type I hair cells were best fitted by using a power function with $N=3.22 \pm 0.71$ and a markedly reduced efficiency (Fig. $7 B$ ). When varying the $\mathrm{Ca}^{2+}$ flux per channel in various extracellular $\mathrm{Ca}^{2+}$ concentrations $(0,1.3$, and $5 \mathrm{~mm} ; 10$ and $20 \mathrm{~mm})$ at constant voltage and duration, Otof ${ }^{-1-}$ type I hair cells also displayed a nonlinear relationship between $I_{\mathrm{Ca}}$ and $\Delta C_{\mathrm{m}}(N=3.38 \pm 0.06)$ and a markedly reduced $\mathrm{Ca}^{2+}$ efficiency (Fig. $7 C$ ).

In mutant type II hair cells, for small depolarizations between -80 and $-10 \mathrm{mV}$ (increasing open channel probability) data were best fitted by using a power function with $N=2.10 \pm 0.20$ and a markedly reduced efficiency of exocytosis compared with wild-type cells (Fig. 7E). Remarkably, for large depolarizations 

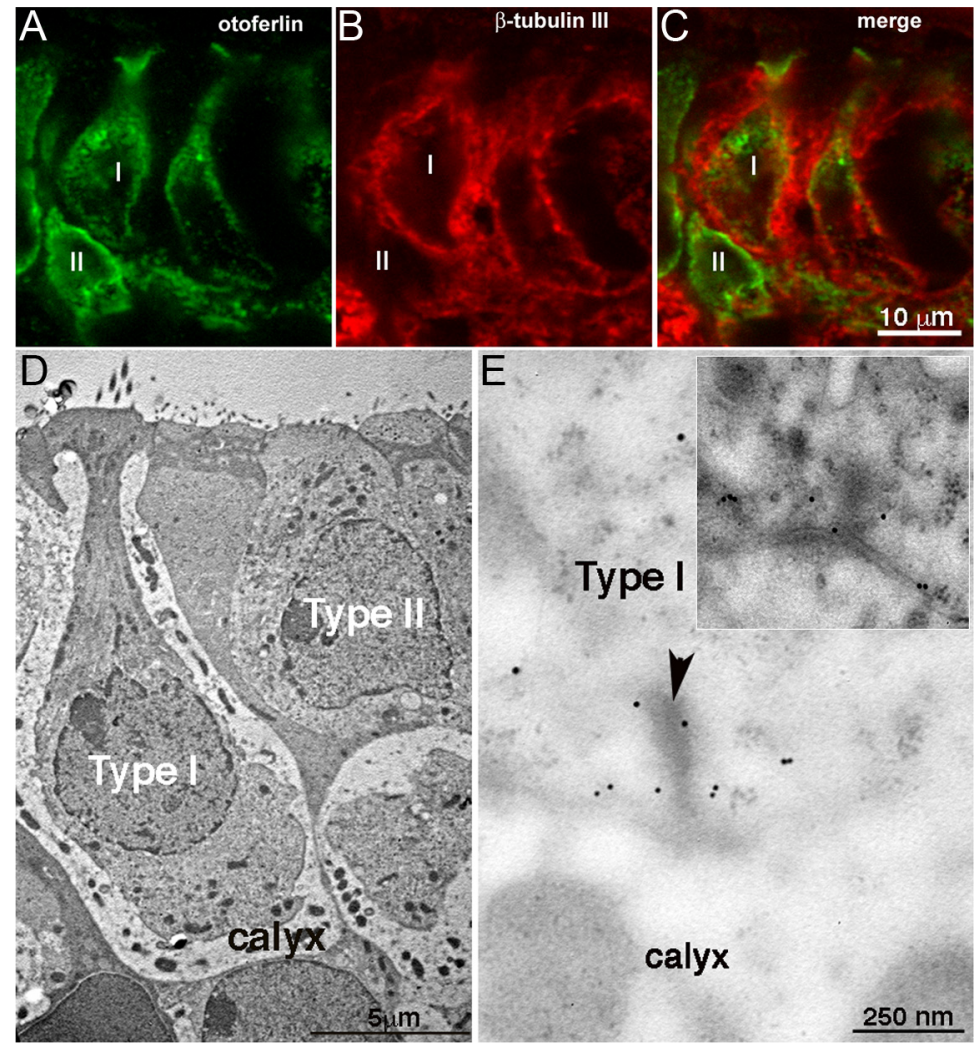

Figure 8. Otoferlin expression in the mouse utricle. $\boldsymbol{A}-\boldsymbol{C}$, Confocal fluorescence microscopy images of a P7 mouse utricle double stained for otoferlin $(\boldsymbol{A})$ and $\beta$-tubulin III (B). Tubulin labels the nerve calyx surrounding type I hair cells. The merged image in $\boldsymbol{C}$ shows otoferlin labeling in a type I hair cell (surrounded by a calyx) and a type II hair cells (no surrounding calyx). D, Transmission electron microscopy showing the two types of hair cells in an adult mouse utricle. $\boldsymbol{E}$, Postembedding immunogold electron microscopy of a section made in a type I hair cell from a P6 mouse utricle, using an anti-otoferlin antibody. Several gold particles are seen around the ribbon (arrowhead) facing the calyx of the afferent neuron. The inset at the top right shows another otoferlin labeling example in which several gold particles are associated with ribbon vesicles and attached to the presynaptic membrane.

wild-type and Otof $^{-1-}$ type II hair cells ( $n=2$; data not shown). These results suggest that the $\mathrm{Ca}^{2+}$ channels are located at a nanometer-sized distance from the release sites in vestibular hair cells.

\section{Vestibular hair cells of Otof ${ }^{-1-}$ mice display morphologically normal ribbon synapses}

We examined whether otoferlin is produced by the two types of vestibular hair cells and whether there are synaptic structural defects in hair cells lacking otoferlin that could explain the abovementioned abnormal exocytosis in these cells. Double-immunolabeling study, using otoferlin and $\beta$-tubulin antibodies to label the hair cells and their afferent nerve endings, respectively, showed similar otoferlin distribution in type I and type II hair cells from the P7 mouse utricle (Fig. $8 A-C)$, saccule, and semicircular canals (data not shown). Notably, otoferlin was detected throughout the cytoplasm from the cuticular plate to the basal synaptic region as reported for cochlear hair cells (Roux et al., 2006). Similar distribution has been reported in cochlear hair cells for the SNARE proteins SNAP25 and syntaxin1 (Safieddine and Wenthold, 1999). These findings are consistent with the proposal according to which the apical part of the hair cells is also involved in vesicle resupply of the ribbon synapse during long stimulations (Griesinger et al., 2005).

between -10 and $+20 \mathrm{mV}$, i.e., at constant maximum open channel probability but decreasing $\mathrm{Ca}^{2+}$ flux per channel, the transfer function between $\Delta C_{\mathrm{m}}$ and $I_{\mathrm{Ca}}$ showed a linear dependence that was approximated by using a power function with $N=$ $0.90 \pm 0.16$, which was not significantly different from wild type with $N=0.80 \pm 0.24$ (Fig. $7 F$ ).

These results show that, for small depolarizations, exocytosis in Otof ${ }^{-1-}$ type I and type II hair cells cannot be approximated by a simple linear transfer function of summed $\mathrm{Ca}^{2+}$ entry. In the absence of otoferlin, exocytosis is much less efficient and functions in a cooperative way.

Sensitivity of exocytosis to internal $\mathrm{Ca}^{2+}$ buffering. The comparative ability of intracellular BAPTA and EGTA to block $\mathrm{Ca}^{2+}$ triggered events is also a way to address the spatial organization of the $\mathrm{Ca}^{2+}$ channels and the $\mathrm{Ca}^{2+}$ sensor (Augustine et al., 2003). The two buffers have a similar equilibrium affinity for $\mathrm{Ca}^{2+}$, but BAPTA displays a 10 times faster rate for $\mathrm{Ca}^{2+}$ binding than EGTA. Therefore, BAPTA is expected to block $\mathrm{Ca}^{2+}$ action within nanodomains, whereas EGTA would only limit intracellular $\mathrm{Ca}^{2+}$ spread in microdomains. An equal BAPTA/EGTA efficacy to block exocytosis would implicate primarily diffused $\mathrm{Ca}^{2+}$ signals such the calyx of Held synapse (Augustine et al., 2003). In wildtype type I hair cells, we found that exocytosis during a $500 \mathrm{~ms}$ pulse depolarization from a holding potential of -80 to $-10 \mathrm{mV}$ was completely blocked by $5 \mathrm{~mm}$ BAPTA $(n=4)$ but unaffected with 5 mM EGTA $(n=5)$ (Fig. $6 B)$. Furthermore, tested in similar conditions, $5 \mathrm{~mm}$ EGTA did not block exocytosis responses in
Postembedding immunogold electron microscopy showed that, just like in cochlear hair cells (Roux et al., 2006), otoferlin is located at the synaptic active zone of vestibular hair cells, including synaptic vesicles and the presynaptic plasma membrane (Fig. $8 E$ ). In the three ribbon-containing active zones analyzed in type I hair cells from P6 mouse utricles, we found that the gold particles were mainly associated with the presynaptic plasma membrane and the vesicles attached to the ribbon. Gold particles were also observed at extrasynaptic zones on the endoplasmic reticulum and Golgi apparatus of the hair cells (data not shown).

Next, we performed a comparative analysis of the ribbon synapse ultrastructure by electron microscopy in vestibular hair cells of P6 wild-type and mutant mice. In both genotypes, we found that type I and type II hair cells have typical ribbon synapses with a distinct postsynaptic density and presynaptic thickening that is marked with a ribbon decorated with synaptic vesicles (Fig. 9) (supplemental Fig. S1, available at www.jneurosci.org as supplemental material). Quantification of the size of the active zones did not show any difference between otoferlin-deficient vestibular synapses and their littermate wild-type controls $(197 \pm 10$ $\mathrm{nm}, n=25$ vs $206 \pm 12 \mathrm{~nm}, n=31 ; p>0.05)$. The number of vesicles associated to the ribbon anchored at the synaptic active zone was also not significantly different $(12 \pm 0.7$ and $15 \pm 1.0$ in mutant and controls, respectively; $p>0.05)$. Two to three vesicles were on average seen docked to the presynaptic plasma membrane below the ribbon, in both wild-type and mutant synapses. 
A double-staining experiment using antibodies against CtBP2 and GluR2/3 to label the ribbon and postsynaptic terminal, respectively (Roux et al., 2006), showed similar GluR2/3 expression in Otof ${ }^{-1-}$ and wild-type utricles (supplementalFig. S2, availableatwww.jneurosci. org as supplemental material). In addition, double staining using antibodies against myosin VIIA and CtBP2 to label the hair cell soma and the ribbons, respectively, did not show any significant difference in the number of ribbons per hair cell between mutant and wild-type hair cells from the central area of the utricle, regardless of the cell type ( $9 \pm$ $0.8, n=63$ vs $7 \pm 1.7, n=56$, respectively; $p>0.05$ ) (supplemental Fig. S3, available at www.jneurosci.org as supplemental material).

Together, these results suggest that synaptic formation and assembly proceed normally in the vestibular hair cells of Otof $^{-1-}$ mice, as reported for cochlear hair cells (Roux et al., 2006). Furthermore, our observation that the numbers of vesicles tethered to the ribbon and docked to the presynaptic plasma membrane are not different between wild-type and mutant mice indicates that neither the biogenesis nor the docking processes of synaptic vesicles are compromised in the mutants. This is consistent with a previous report involving otoferlin in a step downstream from the docking step of synaptic vesicles to the plasma membrane (Roux et al., 2006).

\section{Discussion}

\section{Otoferlin is not essential for} spontaneous synaptic activity

The spontaneous postsynaptic firing activity that was recorded at the afferent calyx endings of vestibular hair cells from Otof $^{-1-}$ mice led us to draw two main conclusions. First, normal spontaneous vesicular release is taking place at the hair cell synapse lacking otoferlin, which is consistent with the morphologically normal synapses observed in these mice. Second, otoferlin is not essential for the associated hair cell synaptic vesicle priming or fusion. In addition, residual evoked vestibular potentials and $\mathrm{Ca}^{2+}$-dependent exocytosis were observed in Otof $^{-/-}$hair cells, indicating that, if otoferlin is a $\mathrm{Ca}^{2+}$ sensor, another one is present in these vestibular mutant hair cells. Such a configuration has already been reported in neuronal synapses and adrenal chromaffin cells in which different $\mathrm{Ca}^{2+}$ sensors may coexist (Xu et al., 2007; Schonn et al., 2008). Because mature hair cells, unlike neurons, do not fire spontaneous action potential, spontaneous transmitter release could involve low voltageactivated $\mathrm{Ca}^{2+}$ channels such as $\mathrm{Ca}_{\mathrm{v}} 3.1 \mathrm{~T}$-type channels (Nie et al., 2008) that can be readily activated near resting membrane potential. The mechanisms of otoferlin-independent vesicular release that drives spontaneous activity in vestibular hair cells remain be elucidated.
Type I hair cells display exocytosis with faster kinetics and higher $\mathrm{Ca}^{2+}$ sensitivity than type II hair cells

To further explore the cause of the defective VsEPs transfer function in Otof ${ }^{-1-}$ mice, we set up to investigate for the first time the mechanisms of $\mathrm{Ca}^{2+}$-dependent exocytosis in mammalian vestibular hair cells. We first established that type I hair cells in wild-type mice display L-type $\mathrm{Ca}^{2+}$ currents activating a fast (RRP) and slow (SRP) phase of exocytosis resembling those previously described in mammalian cochlear hair cells (Moser and Beutner 2000; Johnson et al., 2005; Beurg et al., 2008) and lower vertebrate hair cells (Parsons et al., 1994; Edmonds et al., 2004; Schnee et al., 2005). We found that the RRP exocytosis of type I hair cells displayed activation kinetics ( $\tau=34 \mathrm{~ms}$ ) comparable with that of cochlear hair cells $(\tau=53 \mathrm{~ms})$ but a lower release rate of 110 versus $459 \mathrm{fF} / \mathrm{s}$ (Johnson et al., 2005). However, the release rates become similar when normalized to the number of synaptic ribbons, which is approximately two to four times higher in cochlear inner hair cells than in vestibular hair cells (Roux et al., 2006; Johnson et al., 2008). Together, our results indicate that $\mathrm{Ca}^{2+}$-dependent exocytosis of type I hair cells shares similar characteristics with mature cochlear hair cells in terms of kinetics, $\mathrm{Ca}^{2+}$ sensitivity, and linear $\mathrm{Ca}^{2+}$ dependence. 
Exocytosis in type II hair cells displayed slower kinetics and reduced $\mathrm{Ca}^{2+}$ efficiency compared with type I hair cells. Differences in exocytosis have also been found in the photoreceptors of the retina, with cones showing 10-fold faster kinetics than rods (Rabl et al., 2005), but also between immature and mature cochlear hair cells (Johnson et al., 2005) and between low- and high-frequency gerbil cochlear hair cells (Johnson et al., 2008). Many different factors can influence synaptic exocytosis, such as the presence of different $\mathrm{Ca}^{2+}$ mobile buffers and differences in the intrinsic $\mathrm{Ca}^{2+}$ affinity of the $\mathrm{Ca}^{2+}$ sensor itself (Thoreson, 2007). The implication of several $\mathrm{Ca}^{2+}$-sensing mechanisms, the combination of which could specify the different kinetics of type I and type II vestibular hair cells as reported in the calyx of Held synapse and in adrenal chromaffin cells (Sun et al., 2007; Schonn et al., 2008), should be considered in future studies.

\section{The role of otoferlin in the linear $\mathrm{Ca}^{2+}$ dependence of exocytosis in vestibular hair cells}

We found that exocytosis in wild-type vestibular hair cells displays a remarkable linear $\mathrm{Ca}^{2+}$ dependence when changing $\mathrm{Ca}^{2+}$ entry, by either varying the extracellular $\mathrm{Ca}^{2+}$ concentration, while stepping to different test potentials, or depolarizing the cell for different durations. A similar linear relationship between exocytosis and $\mathrm{Ca}^{2+}$ entry has been obtained in mature cochlear inner hair cells (Moser and Beutner, 2000; Johnson et al., 2005, 2008; Beurg et al., 2008) and in hair cells from the turtle auditory papilla (Schnee et al., 2005).

Experiments with flash photolysis of intracellular caged $\mathrm{Ca}^{2+}$, which directly probe the intrinsic affinity of the $\mathrm{Ca}^{2+}$ sensor (independently of $\mathrm{Ca}^{2+}$ channels), have shown that cochlear inner hair cell exocytosis displays a fifth-order $\mathrm{Ca}^{2+}$ cooperativity in the low micromolar range of $\mathrm{Ca}^{2+}$ concentrations and becomes almost linear above $10 \mu \mathrm{M}$ (Beutner et al., 2001). How is it possible that the $\mathrm{Ca}^{2+}$ sensor has an intrinsic cooperative $\mathrm{Ca}^{2+}$ dependence, whereas exocytosis translates into a linear relation with $\mathrm{Ca}^{2+}$ entry during depolarization? The most likely explanation is that, during voltage activation of $\mathrm{Ca}^{2+}$ channels, the $\mathrm{Ca}^{2+}$ concentration at the release sites instantaneously saturates the $\mathrm{Ca}^{2+}$ sensor. The use of $\mathrm{Ca}^{2+}$-activated $\mathrm{K}^{+}$channels has indeed indicated that the $\mathrm{Ca}^{2+}$ concentration instantaneously rises as much as several hundred micromolar at the active zone of frog saccular hair cells during depolarization (Roberts et al., 1990). In cochlear inner hair cells, the $\mathrm{Ca}^{2+}$ dependence of exocytosis or transmitter release has been shown to be linear when varying the number of open $\mathrm{Ca}^{2+}$ channels and to be highly cooperative when changing the single-channel current (Brandt et al., 2005; Goutman and Glowatzki, 2007). This behavior is compatible with an organization of independent (nonoverlapping) $\mathrm{Ca}^{2+}$ nanodomains, in which the activity of one or few $\mathrm{Ca}^{2+}$ channels is sufficient to activate release of a nearby vesicle (Zucker and Stockbridge, 1983; Zucker and Fogelson, 1986; Augustine, 1990). In contrast, we found here that exocytosis in vestibular type I and type II hair cells is linearly related to cumulative $\mathrm{Ca}^{2+}$ entry, whatever the respective contributions of the $\mathrm{Ca}^{2+}$ channel open probability and $\mathrm{Ca}^{2+}$ flux per channel, which is suggestive of a microdomain-like organization (Engisch and Nowycky, 1996; Mansvelder and Kits, 2000). However, the high BAPTA efficacy relative to the EGTA to block exocytosis in vestibular hair cells argues for a nanometer-sized distance between the calcium sensor and the $\mathrm{Ca}^{2+}$ channels. Moreover, the active zone of vestibular hair cells has an "intrinsic nanometric size" with a diameter of $\sim 200 \mathrm{~nm}$, which might contain as many as $60 \mathrm{Ca}^{2+}$ channels (our estimation). In goldfish or frog saccular hair cells, freeze- fracture electron-microscopy observations of the synaptic active zone have shown the presence of orderly parallel arrays of particles (Hama, 1980; Roberts et al., 1990; Roberts, 1994). These arrays of particles have been suggested to reflect the organization of structures that align $\sim 90 \mathrm{Ca}^{2+}$ channels below the ribbon and where between the rows of particles are possibly located, within $<50 \mathrm{~nm}$, the vesicle attachment sites for synaptic release. Roberts (1994) suggested that such an organization in arrays would bring $\mathrm{Ca}^{2+}$ channels close together and allow $\mathrm{Ca}^{2+}$ activity from different channels to overlap to reach micromolar concentrations at the release sites. Our results, suggesting a cumulative effect of individual $\mathrm{Ca}^{2+}$ currents on exocytosis, are compatible with such a spatial organization of the $\mathrm{Ca}^{2+}$ channels and release site at the synaptic zone of mammalian vestibular hair cells.

The mutant hair cells showed a reduced exocytosis with a nonlinear $\mathrm{Ca}^{2+}$ dependence that is likely related to the intrinsic cooperativity of the synaptic machinery. In Otof ${ }^{-1-}$ type II hair cells, the early rapid phase of exocytosis was less efficient and nonlinearly related to $\mathrm{Ca}^{2+}$ when we varied the number of open $\mathrm{Ca}^{2+}$ channels during small depolarizations, whereas the response became linear when only varying the $\mathrm{Ca}^{2+}$ flux per channel at maximum open channel probability. The "hysteresis" in the curve relating exocytosis to $\mathrm{Ca}^{2+}$ influx is compatible with a cooperative recruitment of $\mathrm{Ca}^{2+}$ domains at small depolarizations in the absence of otoferlin. The results suggest that otoferlin, which can interact with L-type $\mathrm{Ca}_{\mathrm{v}} 1.3 \mathrm{Ca}^{2+}$ channels and SNARE proteins (Roux et al., 2006; Ramakrishnan et al., 2009), works as a high-affinity $\mathrm{Ca}^{2+}$ sensor that allows linearity at low $\mathrm{Ca}^{2+}$ level. The possibility that several calcium-sensing mechanisms underlie the synaptic exocytosis of vestibular hair cells should also be considered. These mechanisms may involve a high-affinity $\mathrm{Ca}^{2+}$-sensing machinery that involves otoferlin $\left(Q_{\mathrm{Ca}}\right.$ below $\left.5 \mathrm{pC}\right)$ and a nonlinear low-affinity calcium-sensing machinery $\left(Q_{\mathrm{Ca}}\right.$ above $\left.5 \mathrm{pC}\right)$. Alternatively, otoferlin may not be the final sensor but be required for the formation of a sensitive, readily saturated, $\mathrm{Ca}^{2+}$-sensing synaptic machinery.

\section{Physiological significance of a linear synaptic transfer at the first synapse in the vestibular pathway}

A linear $\mathrm{Ca}^{2+}$ dependence of transmitter release at the first synapse in the vestibular pathway is certainly essential for an efficient and precise transmission, without distortion, of small sensory signals into the brainstem circuitry of the vestibular ocular reflex. Interestingly, the first central synapse of the vestibular system also displays a remarkable linear relationship between the rate of stimulation of the vestibular afferents and the synaptic charge transfer in postsynaptic vestibular nucleus neurons (Bagnall et al., 2008). The lack of short-term dynamics, facilitation or depression, at these central synapses seems an important feature to ensure linearity. Our findings suggest that the remarkable characteristics of the vestibular system, its temporal precision, sensitivity, and wide dynamic range, first rely on a linear transmission at the hair cell synapse, with otoferlin being critical for exocytosis to achieve a highly sensitive linear $\mathrm{Ca}^{2+}$ dependence.

\section{References}

Almanza A, Vega R, Soto E (2003) $\mathrm{Ca}^{2+}$ current in type I hair cells isolated from the semicircular canal crista ampullaris of the rat. Brain Res 994:175-180.

Augustine GJ (1990) Regulation of transmitter release at the squid giant synapse by presynaptic delayed rectifier potassium current. J Physiol 431:343-364.

Augustine GJ, Santamaria F, Tanaka K (2003) Local calcium signaling in neurons. Neuron 40:331-346. 
Bagnall MW, McElvain LE, Faulstich M, du Lac S (2008) Frequencyindependent synaptic transmission supports a linear vestibular behavior. Neuron 60:343-352.

Bao H, Wong WH, Goldberg JM, Eatock RA (2003) Voltage-gated calcium channel currents in type I and type II hair cells isolated from the rat crista. J Neurophysiol 90:155-164.

Beurg M, Safieddine S, Roux I, Bouleau Y, Petit C, Dulon D (2008) Calcium- and otoferlin-dependent exocytosis by immature outer hair cells. J Neurosci 28:1798-1803.

Beutner D, Voets T, Neher E, Moser T (2001) Calcium dependence of exocytosis and endocytosis at the cochlear inner hair cell afferent synapse. Neuron 29:681-690.

Brandt A, Khimich D, Moser T (2005) Few $\mathrm{Ca}_{\mathrm{V}} 1.3$ channels regulate the exocytosis of a synaptic vesicle at the hair cell ribbon synapse. J Neurosci 25:11577-11585.

Dou H, Vazquez AE, Namkung Y, Chu H, Cardell EL, Nie L, Parson S, Shin HS, Yamoah EN (2004) Null mutation of $\alpha_{1 \mathrm{D}} \mathrm{Ca}^{2+}$ channel gene results in deafness but no vestibular defect in mice. J Assoc Res Otolaryngol 5:215-226.

Eatock RA, Xue J, Kalluri R (2008) Ion channels in mammalian vestibular afferents may set regularity of firing. J Exp Biol 211:1764-1774.

Edmonds BW, Gregory FD, Schweizer FE (2004) Evidence that fast exocytosis can be predominantly mediated by vesicles not docked at active zones in frog saccular hair cells. J Physiol 560:439-450.

Engisch KL, Nowycky MC (1996) Calcium dependence of large dense-cored vesicle exocytosis evoked by calcium influx in bovine adrenal chromaffin cells. J Neurosci 16:1359-1369.

Glowatzki E, Fuchs PA (2002) Transmitter release at the hair cell ribbon synapse. Nat Neurosci 5:147-154.

Goldberg JM (1991) The vestibular end organs: morphological and physiological diversity of afferents. Curr Opin Neurobiol 1:229-235.

Goldberg JM (1996) Theoretical analysis of intercellular communication between the vestibular type I hair cell and its calyx ending. J Neurophysiol 76:1942-1957.

Goldberg JM, Fernandez C (1971) Physiology of peripheral neurons innervating semicircular canals of the squirrel monkey. I. Resting discharge and response to constant angular accelerations. J Neurophysiol 34:635-660.

Goutman JD, Glowatzki E (2007) Time course and calcium dependence of transmitter release at a single ribbon synapse. Proc Natl Acad Sci U S A 104:16341-16346.

Grant L, Fuchs P (2008) Calcium- and calmodulin-dependent inactivation of calcium channels in inner hair cells of the rat cochlea. J Neurophysiol 99:2183-2193.

Griesinger CB, Richards CD, Ashmore JF (2005) Fast vesicle replenishment allows indefatigable signalling at the first auditory synapse. Nature 435:212-215.

Hama K (1980) Fine structure of the afferent synapse and gap junctions on the sensory hair cell in the saccular macula of goldfish: a freeze-fracture study. J Neurocytol 9:845-860.

Hullar TE, Minor LB (1999) High-frequency dynamics of regularly discharging canal afferents provide a linear signal for angular vestibuloocular reflexes. J Neurophysiol 82:2000-2005.

Huterer M, Cullen KE (2002) Vestibuloocular reflex dynamics during highfrequency and high-acceleration rotations of the head on body in rhesus monkey. J Neurophysiol 88:13-28.

Johnson SL, Thomas MV, Kros CJ (2002) Membrane capacitance measurement using patch clamp with integrated self-balancing lock-in amplifier. Pflugers Arch 443:653-663.

Johnson SL, Marcotti W, Kros CJ (2005) Increase in efficiency and reduction in $\mathrm{Ca}^{2+}$ dependence of exocytosis during development of mouse inner hair cells. J Physiol 563:177-191.

Johnson SL, Forge A, Knipper M, Münkner S, Marcotti W (2008) Tonotopic variation in the calcium dependence of neurotransmitter release and vesicle pool replenishment at mammalian auditory ribbon synapses. J Neurosci 28:7670-7678.

Jones SM, Erway LC, Bergstrom RA, Schimenti JC, Jones TA (1999) Vestibular responses to linear acceleration are absent in otoconia-deficient C57BL/6JEi-het mice. Hear Res 135:56-60.

Jones SM, Jones TA, Johnson KR, Yu H, Erway LC, Zheng QY (2006) A comparison of vestibular and auditory phenotypes in inbred mouse strains. Brain Res 1091:40-46.
Keen EC, Hudspeth AJ (2006) Transfer characteristics of the hair cells' afferent synapse. Proc Natl Acad Sci U S A 103:5537-5542.

Khimich D, Nouvian R, Pujol R, Tom Dieck S, Egner A, Gundelfinger ED, Moser T (2005) Hair cell synaptic ribbons are essential for synchronous auditory signalling. Nature 434:889-894.

Kits KS, de Vlieger TA, Kooi BW, Mansvelder HD (1999) Diffusion barriers limit the effect of mobile calcium buffers on exocytosis of large dense cored vesicles. Biophys J 76:1693-1705.

Lee HY, Camp AJ, Callister RJ, Brichta AM (2005) Vestibular primary afferent activity in an in vitro preparation of the mouse inner ear. J Neurosci Methods 145:73-87.

Lenzi D, Runyeon JW, Crum J, Ellisman MH, Roberts WM (1999) Synaptic vesicle populations in saccular hair cells reconstructed by electron tomography. J Neurosci 19:119-132.

Longo-Guess C, Gagnon LH, Bergstrom DE, Johnson KR (2007) A missense mutation in the conserved C2B domain of otoferlin causes deafness in a new mouse model of DFNB9. Hear Res 234:21-28.

Mansvelder HD, Kits KS (2000) All classes of calcium channel couple with equal efficiency to exocytosis in rat melanotropes, inducing linear stimulus-secretion coupling. J Physiol 526:327-339.

Meyer AC, Frank T, Khimich D, Hoch G, Riedel D, Chapochnikov NM, Yarin YM, Harke B, Hell SW, Egner A, Moser T (2009) Tuning of synapse number, structure and function in the cochlea. Nat Neurosci 12:444-453.

Moser T, Beutner D (2000) Kinetics of exocytosis and endocytoiss at the cohlear inner hair cell afferent synapse of the mouse. Proc Natl Acad Sci U S A 97:883-888.

Nazareth AM, Jones TA (1998) Peripheral and central components of short latency vestibular evoked potentials. J Vestib Res 8:233-252.

Nie L, Zhu J, Gratton MA, Liao A, Mu KJ, Nonner W, Richardson GP, Yamoah EN (2008) Molecular identity and functional properties of a novel T-type $\mathrm{Ca}^{2+}$ channel cloned from the sensory epithelia of the mouse inner ear. J Neurophysiol 100:2287-2299.

Nouvian R, Beutner D, Parsons TD, Moser T (2006) Structure and function of the hair cell ribbon synapse. J Membr Biol 209:153-165.

Parsons TD, Lenzi D, Almers W, Roberts WM (1994) Calcium-triggered exocytosis and endocytosis in an isolated presynaptic cell: capacitance measurements in saccular hair cells. Neuron 13:875-883.

Rabl K, Cadetti L, Thoreson WB (2005) Kinetics of exocytosis is faster in cones than in rods. J Neurosci 25:4633-4640.

Ramakrishnan NA, Drescher MJ, Barretto RL, Beisel KW, Hatfield JS, Drescher DG (2009) Direct interaction of otferlin with syntaxin 1A, SNAP-25, and the L-type voltage calcium channel Cav1.3. J Biol Chem 284:3227-3238.

Roberts WM (1994) Localization of calcium signals by a mobile calcium buffer in frog saccular hair cells. J Neurosci 14:3246-3262.

Roberts WM, Jacobs RA, Hudspeth AJ (1990) Colocalization of ion channels involved in frequency selectivity and synaptic transmission at presynaptic active zones of hair cells. J Neurosci 10:3664-3684.

Roux I, Safieddine S, Nouvian R, Grati M, Simmler MC, Bahloul A, Perfettini I, Le Gall M, Rostaing P, Hamard G, Triller A, Avan P, Moser T, Petit C (2006) Otoferlin, defective in a human deafness form, is essential for exocytosis at the auditory ribbon synapse. Cell 127:277-289.

Rüsch A, Lysakowski A, Eatock RA (1998) Postnatal development of type I and type II hair cells in the mouse utricle: acquisition of voltage-gated conductances and differentiated morphology. J Neurosci 18:7487-7501.

Safieddine S, Wenthold RJ (1999) SNARE complex at the ribbon synapses of cochlear hair cells: analysis of synaptic vesicle- and synaptic membraneassociated proteins. Eur J Neurosci 11:803-812.

Schnee ME, Lawton DM, Furness DN, Benke TA, Ricci AJ (2005) Auditory hair cell-afferent fiber synapses are specialized to operate at their best frequencies. Neuron 47:243-254.

Schonn JS, Maximov A, Lao Y, Südhof TC, Sørensen JB (2008) Synaptotagmin-1 and -7 are functionally overlapping $\mathrm{Ca}^{2+}$ sensors for exocytosis in adrenal chromaffin cells. Proc Natl Acad Sci U S A 105:3998-4003.

Schug N, Braig C, Zimmermann U, Engel J, Winter H, Ruth P, Blin N, Pfister M, Kalbacher H, Knipper M (2006) Differential expression of otoferlin in brain, vestibular system, immature and mature cochea of the rat. Eur J Neurosci 24:3372-3380.

Schwander M, Sczaniecka A, Grillet N, Bailey JS, Avenarius M, Najmabadi H, Steffy BM, Federe GC, Lagler EA, Banan R, Hice R, Grabowski-Boase L, Keithley EM, Ryan AF, Housley GD, Wiltshire T, Smith RJ, Tarantino LM, Müller U (2007) A forward genetics screen in mice identifies reces- 
sive deafness traits and reveals that pejvakin is essential for outer hair cell function. J Neurosci 27:2163-2175.

Sun J, Pang ZP, Qin D, Fahim AT, Adachi R, Südhof TC (2007) A dual$\mathrm{Ca}^{2+}$-sensor model for neurotransmitter release in a central synapse. Nature 450:676-682.

Thoreson WB (2007) Kinetics of synaptic transmission at ribbon synapses of rods and cones. Mol Neurobiol 36:205-223.

Xu J, Mashimo T, Südhof TC (2007) Synaptotagmin-1, -2, and -9: $\mathrm{Ca}^{2+}$ sensors for fast release that specify distinct presynaptic properties in subsets of neurons. Neuron 54:567-581.

Yang PS, Alseikhan BA, Hiel H, Grant L, Mori MX, Yang W, Fuchs PA, Yue DT (2006) Switching of $\mathrm{Ca}^{2+}$-dependent inactivation of $\mathrm{Ca}_{\mathrm{v}} 1.3$ chan- nels by calcium binding proteins of auditory hair cells. J Neurosci 26:10677-10689.

Yasunaga S, Grati M, Cohen-Salmon M, El-Amraoui A, Mustapha M, Salem N, El-Zir E, Loiselet J, Petit C (1999) A mutation in OTOF, encoding otoferlin, a FER-1-like protein, causes DFNB9, a nonsyndromic form of deafness. Nat Genet 21:363-369.

Zucker RS, Fogelson AL (1986) Relationship between transmitter release and presynaptic calcium influx when calcium enters through discrete channels. Proc Natl Acad Sci U S A 83:3032-3036.

Zucker RS, Stockbridge N (1983) Presynaptic calcium diffusion and the time courses of transmitter release and synaptic facilitation at the squid giant synapse. J Neurosci 3:1263-1269. 